\title{
Toward an Understanding of Aggregate Death Penalty Opinion Change: A Possible Role for Popular Music
}

\author{
Robert M. Bohm* and Ray Surette
}

Department of Criminal Justice, University of Central Florida, Orlando, FL 32816, USA

\begin{abstract}
This study examines the relationship between popular music; specifically, death penalty songs, and aggregate death penalty opinion change utilizing an exploratory time series analysis. An assumption of this study is that the public is made conscious of the death penalty as a salient issue through the popular media, e.g., newspaper stories, magazine articles, movies, television programs, and music. Results of this study support the hypotheses that public consciousness about the death penalty as well as changes in aggregate death penalty opinion are associated with the content of popular media in the form of death penalty songs. As the number of death penalty songs increases in a year, death penalty support decreases two years later.
\end{abstract}

Keywords: Death penalty opinion, capital punishment, media, death penalty songs, music.

\section{INTRODUCTION}

Prior research has reported a link between media content and public opinions toward the death penalty. However, this research has focused mainly on print media. Whether an association extends to other types of media remains an unanswered question. This study examines the relationship between popular music; specifically, death penalty songs, and aggregate death penalty opinion change utilizing an exploratory time series analysis. An assumption of this study is that the public is made conscious of the death penalty as a salient issue through the popular media, e.g., newspaper stories, magazine articles, movies, television programs, and music. This exploratory study contributes to an understanding of aggregate death penalty opinion change by examining an additional previously unexamined possible source of death penalty consciousness.

Aggregate death penalty opinion is important to study and understand because such opinion, perhaps more than any other factor, influences the continued use of capital punishment in many jurisdictions in the United States. If most citizens in death penalty jurisdictions opposed capital punishment, it is unlikely the penalty would be employed. In the 1980s, attorney David Bruck predicted that the death penalty's "political potency" could be effectively neutralized if only a quarter to a third of death penalty proponents could be convinced to oppose the penalty (cited in Haines, 1996: 164).

*Address correspondence to this author at the Department of Criminal Justice, University of Central Florida, Orlando, FL 32816, USA; Tel: 407-823-5944; E-mail: Robert.Bohm@ucf.edu
Strong public support may contribute to the continued use of capital punishment in a number of other ways as well. First, it probably sways legislators to vote in favor of death penalty statutes (and against their repeal) (Dieter, 1996). Second, strong public support likely influences some prosecutors to seek the death penalty for political rather than legal purposes in cases where they might ordinarily plea bargain (White, 1987: 17; also see Dieter, 1996; Callahan et al., 2000). Third, to retain their positions, some trial-court judges feel public pressure to impose death sentences in cases in which such actions are inappropriate, and some appellate-court judges may uphold death sentences on appeal when they should not (Bright, 1998; Dieter, 1996; Bright and Keenan, 1995; Dickson, 2006: 281). Fourth, some governors may be dissuaded from vetoing death penalty legislation and commuting death sentences because of strong public support for the penalty (Baldus and Woodworth, 1998: 388-9; also see Burnett, 2002; Kobil, 2003; Dieter, 1996). Fifth, and arguably most important, strong public support might be used, at least indirectly, by justices of both state supreme courts and the United States Supreme Court as a measure of evolving standards of decency regarding what constitutes cruel and unusual punishment in state constitutions and under the Eighth Amendment of the United States Constitution. ${ }^{1}$ Regarding the U.S. Supreme Court, Baumgartner et al. claim that "the majority opinion in each major death

\footnotetext{
${ }^{1}$ On state constitutions, see Bedau, 1987, Chap. 8; on the Eighth Amendment, see Marshall in Furman v. Georgia, 1972:329; also in Furman: Douglas, p. 242, Brennan, pp. 269-70; Burger, p. 383, and Powell, p. 409; Trop v. Dulles, 1958:101; Weems v. United States, 1910:349, 373; Robinson v. California, 1962:666; also cf. Estelle v. Gamble, 1976:102; Roberts v. Louisiana, 1976:336, 352; Woodson v. North Carolina, 1976:301; Gregg v. Georgia, 1976:173, 227. But see Justice Rehnquist's dissent in Atkins v. Virginia, 2002 where he is highly critical of using public opinion as a measure of evolving standards of decency.
}

E-ISSN: $1929-4409 / 13$ (c) 2013 Lifescience Global 
penalty decision in the last century cited polling data by Gallup or other major survey houses in support of the ruling, whether for or against capital punishment" (Baumgartner et al., 2008: 169).

\section{RESEARCH ON AGGREGATE DEATH PENALTY OPINION CHANGE}

Much of the research on aggregate death penalty opinion change has been conducted at the individual level of analysis where the focus has been the demographic characteristics that distinguish death penalty proponents from death penalty opponents. Based on more than 70 years of this research, whites, males, Republicans, and wealthier people have been more likely to support the death penalty than nonwhites, females, Democrats, and poorer people (see Bohm, 2012: 326-328). Other demographic characteristics have not been shown to consistently align with death penalty support or opposition to the degree of those mentioned above.

Research shows that most Americans have an opinion about the death penalty even though they know little about the subject (see Sarat and Vidmar, 1976: Ellsworth and Ross, 1983; Bohm, Clark, and Aveni, 1990; Bohm, Clark, and Aveni, 1991; Wright, Bohm, and Jamieson, 1995; Cochran and Chamlin, 2005; Cochran, Sanders and Chamlin, 2006). ${ }^{2}$ What most Americans think they know about the death penalty, moreover, often turns out to be wrong. If death penalty opinions are not knowledge based or are not based on accurate knowledge, obvious questions are what is their source and how and why do they change?

When people are presented with accurate information about the death penalty, studies reveal that the information can polarize opinions, instead of changing them from in favor to opposed or vice versa (Lord et al., 1979; also see Ellsworth and Ross, 1983; Bohm et al., 1990; Bohm, 1990). In other words, some people who initially favor the death penalty tend to favor it more strongly after receiving information about it, while some people who initially oppose the death penalty tend to oppose it even more after becoming informed. The researchers attribute polarization to biased assimilation, that is, subjects interpret evidence so as to maintain their initial beliefs.

Studies also have shown that people who change their death penalty opinions, as a result of becoming

${ }^{2}$ In none of these studies did subjects, on average, answer correctly more than 52 percent of the knowledge items. informed about the penalty, may do so only temporarily. After the passage of time, their changed opinions may rebound to their initial uninformed positions (Bohm et al., 1993; Bohm and Vogel, 2004).

Finally, research shows that people who support the death penalty primarily for retributive reasons generally are impervious to persuasion (Sarat and Vidmar, 1976; Bohm et al., 1991; Bohm and Vogel, 2004, Cochran et al., 2006, but see Cochran and Chamlin, 2005), which also may be true of people who support the death penalty primarily for moral or religious reasons (Baumgartner et al., 2008: 184).

\section{THEORIES OF AGGREGATE DEATH PENALTY OPINION CHANGE}

The aforementioned research suggests that death penalty opinion is resistant to change, but it does vary over time, sometimes dramatically. Several theories have been advanced to explain aggregate death penalty opinion change. One theory, for example, posits that death penalty opinion is influenced by developing moral judgment in society, and that eventually society will morally progress to a stage where the public will not support the death penalty (Kohlberg and Elfenbein, 1975).

A second theory suggests that the formation of death penalty opinions begins in the family and is spread by moral crusaders (Gelles and Straus, 1976). However, if death penalty opinions are rooted in the family-conveyed by parents to their children, as Gelles and Straus maintain-one must still ask from where do parents acquire death penalty opinions? Besides their own parents, Gelles and Straus suggest that death penalty opinion is a product of "effective moral crusades by individuals who, for a variety of reasons, advocate [or oppose] use of the death penalty" (Gelles and Straus, 1976: 230). In other words, moral crusaders persuade parents, who teach their children, that the death penalty is or is not a legitimate and appropriate response for certain crimes. Still, why do moral crusaders support or oppose the death penalty, and how do they convey their message to the public? Regarding the first question, Gelles and Straus write, "for a variety of reasons" (Gelles and Straus, 1976: 230). As for the second question, we argue that a significant portion of the message is circulated through the popular media.

More recently, Bohm attempted to explain the dramatic reversal in death penalty opinion in the United 
States beginning in the 1966 to 1967 period. From his analysis, Bohm concluded, "The key to understanding temporal variations in death penalty opinions probably lies in the fear and anxiety engendered by the social events of an era" (Bohm, 1992: 539; also see Baumgartner et al., 2008: 184). The strength of death penalty support and opposition, according to Bohm, appears to be both a psychological barometer of the level of dread and angst in a society and a symbolic marker of the social landscape. In particular, levels of support and opposition seem to demarcate the threshold level of people's tolerance of media-reported crime, and, at the same time, serve as an indicator of people's threshold tolerance of social change. As one student of the subject put it, death penalty support declined in the 1960s because, "as practiced, many people found [the death penalty] to be glaringly inconsistent with the ascendant ideas of the times" (Haines, 1996: 161). Bohm believes it is reasonable to assume "that historical changes, such as a political shift away from the conservative social policies of the last [two and a half decades or so], are apt to either produce a dramatic shift in future death penalty opinions or to be marked by changed death penalty opinions as the political shift passes a certain threshold level" (Bohm, 1992; also see Zimring, 2003).

The idea that the death penalty has symbolic importance suggests that death penalty opinion is not really about the death penalty per se but rather reflects more fundamental social issues, such as support for law enforcement. Law enforcement officials commonly employ death cases and infamous homicides as "symbolic crimes," which further marries the specific issue of capital punishment with other law enforcement issues. The death penalty as symbol makes sense because the death penalty has limited salience for most people. Few people have had any contact with the death penalty process either as offenders, offender family members, victim family members, jurors, or witnesses. Nor have they had direct contact with others in those situations.

By default, most people are dependent on the media for whatever information they acquire. So, if people give any thought to the death penalty, it is mostly an abstract or theoretical issue with little, if any, practical significance for them. The first time many people may think about the death penalty or develop a death penalty consciousness is when they are asked for their opinion. The question instigates a process by which the person responds based on what would be expected given the person's unique demographic characteristics. Thus, if a person is politically conservative and lacking direct experience with the death penalty, all other things being equal, that person is likely to report that he or she is in favor of the death penalty.

Songs about the death penalty are hypothesized to work in much the same way as questions on a death penalty survey. They are a basis for the formation of a death penalty consciousness. From this expectation it is predicted that the number of death penalty songs circulating will be associated with shifts in death penalty opinion. In this perspective, the presence of death penalty songs does not alter opinion as much as crystalize opinion that would be expected given an individual's demographic characteristics. Furthermore, if the death penalty plays a symbolic role, death penalty songs may embody and bring to public consciousness salient social issues that, themselves, may affect death penalty opinion. At the least, songs about the death penalty probably would not be produced in a social context that was not already primed for them, that is, if the popular media were not already disseminating captivating narratives about the death penalty.

\section{MEDIA INFLUENCE ON AGGREGATE DEATH PENALTY OPINION CHANGE RESEARCH}

Initial research on a media-criminal justice policy relationship concentrated on describing the relationship between the media and broad criminal justice policy support. For example, Fishman's (1978) study of a New York City media-constructed crime wave against the elderly detailed how a few incidents were covered extensively in the media, followed by changes in citizens' perceptions about crimes against the elderly, and strong public policy responses involving a special elderly investigation unit and new legislation. The majority of research in this tradition looked at the media as generators of fear of crime, with many studies showing relationships among the level of exposure to crime news, entertainment programming, and consumers' heightened fear of victimization and moral panics (see Chermak 1998, Cohen 2002, Fishman 1978, Jenkins 1998 and Lawrence and Mueller 2003). Roomer and colleagues (2003), for example, found that the more television people watched, the more likely they believed they would be crime victims. Collectively, this body of research supports the argument that sensational media images of crime foster a narrow punitive view of criminal justice policy due to the public accepting a media-constructed hyper-violent crime portrait, perceiving the criminal justice system as soft, 
and accepting crime control as the best course of action (Beckett and Sasson, 2000; Claussen, 2004; Dowler, 2003; Kappeler et al., 2000; Kiousis, 2001).

Only a few studies have specifically addressed the media's relation to death penalty opinion. For example, Lipschultz and Hilt (1999) discussed how the portrayal of three Nebraska executions in the news framed death penalty support as unquestioned and not worthy of debate or research. Niven (2002) reported that exposure to print stories containing either a limited or an expanded description of the level of death penalty support appeared to influence death penalty support among his subjects. Holbert, Shah and Kwak (2004) found that viewing three types of television content was associated with death penalty support. They found that viewing police reality shows was both directly and indirectly related to support, that television news viewing predicted fear of crime that in turn contributed to death penalty support, and that viewing crime dramas was positively related to death penalty support. Along similar lines, Slater, Rounder, and Long (2006) found that support for the death penalty was positively influenced by watching a television crime drama--in their study an episode of Law and Order in which capital punishment was a central theme.

More recently, Baumgartner and his colleagues have argued that the decrease in death penalty support (and the number of death sentences and executions) beginning in the mid-1990s was due to the "discovery of innocence," that is, the recognition by the public of fundamental flaws in the administration of the death penalty in general and of miscarriages of justice (e.g., wrongful convictions and, perhaps, even wrongful executions) in particular (Baumgartner et al., 2008: 910). The contention that the death penalty process is flawed and that innocent people are wrongly convicted and executed is not new. What is new, according to Baumgartner et al., is that those issues have been "framed" differently by the media. "Framing," writes Baumgartner et al., is "a natural part of the political process" and refers to "defining an issue along a particular dimension (e.g., fairness and innocence) at the exclusion of alternate dimensions (e.g., morality, constitutionality, or cost) (Baumgartner et al., 2008: 4). Baumgartner et al. describe how certain events and the innocence frame changed aggregate death penalty opinion: "Successful demonstration of innocence by students [in university-based innocence projects] led lawmakers and governors to take the issue seriously. Official investigations into errors of justice led to further news coverage and news coverage affected public thinking" (Baumgartner et al., 2008: 101). Regarding the increase in news coverage, the researchers note: "exonerated defendants today receive more than ten times the number of stories, per individual, than those who were exonerated before 1991" (Baumgartner et al., 2008: 101). Based on an elaborate methodological scheme, Baumgartner et al. discovered "that net support for the death penalty is strongly affected by both homicide rates and the tone of media coverage [i.e., whether an article "had an overall pro-or antideath penalty orientation"]. In fact, the overall impact of the net tone of media coverage ... appears to be equal to that of movements in homicide levels over the last forty years" (Baumgartner et al., 2008: 167). Regarding death penalty opinion, the media's construction of the reality of capital punishment was as important as the reality of homicide.

\section{MEDIA INFLUENCE ON AGGREGATE DEATH PENALTY OPINION CHANGE THEORY}

Based on the premise that media can influence death penalty opinion, an important question is by what mechanisms do the media influence opinion. Communication research has delineated three models through which media content can influence public opinion. Two models involve the cognitive processing of media-supplied information by consumers (Shrum, 2002: 71), and the third model involves interaction with media provided narratives (Green and Brock, 2000). In the cognitive processing models, the impact of media on persuasion depends upon an individual's cognitive motivation (his or her willingness to invest time gathering and evaluating information). In these models, individuals are either highly or moderately active participants in the process and relate media content to their pre-existing cache of information. People's cognitive responses to the media-supplied information, rather than learning the information per se, determine the extent of media influence (Petty, Priester, and Brinol, 2002: 164; also see Petty and Cacioppo, 1981, 1986; Petty and Wegener, 1999). The cognitive processing models have been applied primarily to news media content and provide an explanatory mechanism for understanding Baumgartner's and colleagues findings.

The two cognitive processing models are "systematic central processing," by which all relevant and available information is collected and assessed before an opinion is formed, and "heuristic peripheral processing," by which opinions are formed and decisions are made based on incomplete information. 
When motivation is high and the opinion issue is important to the individual, systematic central processing is followed, as long as the individual has the capability to understand the information gathered. When cognitive motivation is low, heuristic peripheral processing is followed, resulting in more spontaneous emotive-based opinions. The heuristic peripheral processing model appears to better capture the responses of most people, when they are provided factual information about the death penalty. Those comparatively few with deep investment in the issue would follow the systematic processing model.

The third model of media influence is the "narrative persuasion" model, which, unlike the two cognitive processing models, captures the phenomenological experience of hearing, reading, or viewing a mediasupplied story. Narrative persuasion requires an individual's absorption into the media narrative. While in the cognitive processing models, the critical element is the amount of thought an individual devotes to evaluating a message, in narrative persuasion the individual is temporarily distanced from his or her current beliefs, experiences, and assessments of the validity of media content but not its effects (Green and Brock, 2000: 702). Thus, even when the narrative is clearly labeled as fiction and is delivered via "logic-free" media such as commercial films or popular songs, beliefs about the real world can be affected. Once a listener is absorbed in a compelling narrative, the credibility of the media source is less important so that the opinion position implied in a death penalty song, for example, can be influential regardless of how realistic, logical, or factual the narrative is (Green and Brock, 2000: 718-719). An important way in which the narrative persuasion model differs from the cognitive processing models is that the narrative persuasion model precludes counterarguing (the questioning of the credibility and the validity of media-supplied information) by the media consumer. Counterarguing is common in the systematic central processing model and less but still present in the heuristic peripheral processing model. The narrative persuasion model, therefore, provides a means to influence individuals who would ordinarily be resistant to persuasion (Slater and Rouner, 2002: 180).

Lastly, the narrative persuasion model holds that consumer demographic similarity to characters in a narrative is less important than how emotionally involved the consumer becomes with those characters
(Slater and Rouner, 2002: 186). Particularly important for this study, the narrative persuasion model predicts that the opinions of initially unsympathetic audience members can be influenced by transitional narratives involving characters who initially espouse counter beliefs but come to model the opinion change for the consumer (Slater and Rouner, 2002: 185). Thus, a media supplied narrative that depicts a charater changing from supportive to unsupportive of the death penalty can influence a narratively engaged consumer to do the same where a logical fact-based argument might not. Whether such effects occur is beyond the scope of this study and before a causal relationship can be empirically researched, it must first be established that a significant association exists betweeen death penalty songs and death penalty opinions. If correlation and time order can be demonstrated and spuriousness can be rejected, a search for causal relationships can follow.

Song and ballad narratives about crime and justice issues have a long history with roots to the Middle Ages (Surette, 2007). Popular music has been a comparatively stable media mainstay over the course of the death penalty debate and the ebbs and flows of public support. While its content regarding how homicide and violence are portrayed has been examined, especially in rap, music has not been studied as a possible contributor to the death penalty debate. ${ }^{3}$ In response, this exploratory study tests the hypothesis that popular songs about the death penalty as a widely available source of narrative persuasion are related to death penalty opinion change.

\section{METHODS}

Data

Much of the data employed in this study were from files provided by Frank Baumgartner on a web site that is no longer active. The data were used in the research for his book, The Decline of the Death Penalty and the Discovery of Innocence (Cambridge University Press, 2008), written with Suzanna L. DeBoef and Amber E. Boydstun. The data covered the period from 1976 through 2006. Where possible, these data were

${ }^{3} \mathrm{~A}$ number of content analysis studies have examined how music is related to crime and justice. Studies of song lyrics report that homicide and violence are freqeuntly constructed as glorified and normalized (see for example Armstrong 1993, Binder 1993, Hunnicutt and Andrews 2009, and Kubrin 2005). 
augmented with data from 2007 and 2008. The authors of this study collected song data, as described below. ${ }^{4}$

The study began with measures reflecting four conceptual variable groups: death penalty songs, criminal justice activities related to capital punishment, societal crime levels, and death penalty related news. Death penalty song trends were the predictor variables of interest with capital punishment related justice activities, crime levels, and death penalty news utilized as control variables.

\section{Variables}

\section{Dependent Variable}

The dependent variable is death penalty support, which was measured using the percentage of affirmative responses to the standard Gallup poll death penalty opinion question: "Are you in favor of the death penalty for a person convicted of murder?" Responses were from the 1976 through 2006 polls found in the Baumgartner data files. Percentages for 2007 and 2008 were obtained from the Death Penalty Information Center web site at www.deathpenaltyinfo.org/publicopinion-about-death-penalty.

\section{Independent Variables}

Unique to this research effort is the assessement of popular song content regarding capital punishment for each examined year. Three time series about death penalty songs were collected (number of songs per year, song tone-either pro-death penalty, anti-death penalty, or neutral, and song popularity). Death penalty songs were compiled via a two-prong search. First, using www.songlyrics.com as the search base, a list was compiled from songs released between 1976 and 2008 that used the keyword execution. This search produced 297 songs with the word execution in the lyrics. Using www.songlyrics.com, the lyrics as well as the artist, name of song, and album were retrieved. The lyrics for each song were reviewed and 30 of the 297 songs met the criterion of explicitly discussing the death penalty or describing an execution. A second list was compiled using the keywords: guillotine, noose, electric chair, death row, hanging, gas chamber, and death. The lyrics to those songs were also reviewed,

\footnotetext{
${ }^{4}$ Death penalty-focused commercial films also were considered but for the 1976-2008 period, only 20 death penalty films were found. Moreover, 19 years had zero qualifying films. With only 14 years in which films about capital punishment were released and numerous gaps in the data series, a time series analysis of a possible association between public opinion and film was not feasible. A list of death penalty movies was generated from a search engine keyword search using www.imdb.com.
}

and an additional 42 songs met the criterion and were selected. Thus, a total of 72 songs made the final list. The 72 songs represented four genres: rock (50), rap (15), folk (2), and other (5).

The lyrics were then reviewed a second time to determine whether the song was a pro-death penalty song, an anti-death penalty song, or a neutral death penalty song. Each song was coded as +1 for prodeath penalty song, -1 for anti-death penalty song, and 0 for songs that were neither pro-death penalty nor anti-death penalty. Each year's value was the average score of all execution songs for that year, which provided the measure for the variable "song tone." Following are examples of pro-death penalty, antideath penalty, and "neutral" death penalty songs and lyrics:

Example of pro-death penalty song and lyrics: Death Penalty by Witchfinder General. "Life in prison is not enough for what they do ... a life for a life, that's the way ... the chair is best."

Example of anti-death penalty song and lyrics: Ride the Lightning by Metallica. "Guilty as charged, but damn it, it ain't right. Strapped in the electric chair, this can't be happening to me. Who made you God to say l'll take your life from you."

Example of neutral death penalty song and lyrics: Let the Killing Begin by Arch Enemy. "On death row, awaiting my fate, sacrificed upon the alters [sic] of justice ... on my way to depart from life. Let the killing begin, let them end your life of $\sin . "$

The third song variable, a death penalty song's populatity, was assessed by whether it was ranked in the Billboard top 100 at any time. This was determined by using information from www.billboard.com. If the song or its album had reached the charts, the number of weeks on the chart and peak listing were recorded. Twenty-two death penalty songs in total reached the top 100 chart: 5 individual songs and 17 albums.

Reflecting the assumption that more popular songs would be heard by more people and therefore potentially be more influential on public opinions, all execution songs were scored 3 if both the song and its album made the top 100, 2 if only the song made the top 100,1 if only the album made the top 100 , and 0 if neither the song nor the album made the top 100 . These values were then multiplied by the songs pro or anti-death penalty position as described above to provide a final measure that ranged from -3 to +3 , 
where negative values denote a song's anti-death penalty position and its popularity and positive values denote a song's pro-death penalty position and popularity. Each year's value was the simple average of the scores for all songs for that year and provided the measure for "song popularity." See Appendix 1 for death penalty song data.

\section{Control Variables}

Three capital punishment measures were employed as control variables: the number of death row inmates, the number of death sentences imposed, and the number of death row exonerations. Annual information about crime was the basis for six control variables: the number and the rate of violent crimes, the number and the rate of property crimes, and the number and the rate of murders. Lastly, annual data regarding news media coverage of capital punishment was the basis for nine more control variable series: the number of The New York Times death penalty stories, the number of front-page death penalty stories, the number of death penalty efficacy stories, the number of morality stories, the number of fairness stories, the number of constitutionality stories, the number of pro-death penalty and anti-death penalty stories, as well as the number of death penalty stories reported in the Readers Guide. A description of the death penalty, crime, and news media variables can be found in Appendix 2.

\section{ANALYSIS AND RESULTS}

To avoid a problem frequently encountered in timeseries analyses - the problem of variables being related to "time" but not to each other and thereby producing false conclusions about relationships between variable series-variable series were first examined for stationarity or autocorrelation. Because evidence of autocorrelation was found, it was necessary to move the variable series toward stationarity for analysis. To do so, all variable series were "first differenced" (i.e., the value of a year was subtracted from the value of the prior year). Thus, what was empirically examined in the analysis were these "differences" for each variable series using the cross correlation function in SPSS. This function also allowed for the examination of the time order of the variable series by providing the correlations of lagged values to see if changes in music preceded changes in opinion, as opposed to vice versa.

\section{Bivariate Analysis}

Following the above logic, time series cross correlations between the annual variations in each independent variable series, each control variable series, and each dependent variable series were examined across rolling six-year time spans. The expectation was that significant associations, if they existed, should emerge within two to three years. In this process, the correlation between the variations in death penalty support with the variations in an expected predictor or control variable were calculated and examined for each instant year with three prior years and three subsequent years.

Cross correlations allowed for a direct examination of the time order among the variables via the interpreation of four general outcomes. First, if none of the cross-corrrelations was significant, then shifts in the two variables would obviously not be related. Second, if shifts in songs were significantly correlated with later shifts in death penalty opinion, then a potential for a music-to-opinion effect would exist. Third, if shifts in opinion were significantly correlated with later shifts in songs, then the necessary time order for a music effect would not exist but the possibility of public opinion influencing song production would. Fourth, if significant cross correlations existed both prior to and following opinion shifts than a mixed simultaneous influence would be supported. In sum, the existence of significant later year correlations indicate that variations in death penalty support predict variations in an independent variable-contrary to the time-order relationship of music as an influence on opinion. On the other hand, significant prior year cross correlations would indicate that variations in death penalty songs predict variations in death penalty support-consistent with a possible media effect on opinion.

The aforementioned procedure produced eight statistically significant relationships that were in the necessary time order; that is, where a statistically significant $(p<.05)$ lead correlation for death penalty support was observed within a three-year span. One relationship involving the number of death row inmates was significant but temporally reversed, and the remaining 13 relationships were all insignificant. ${ }^{5}$ The cross-correlation functions that revealed a statistically significant lead association with death penalty support were death penalty songs; number of executions; number and rate of violent crimes; number of murders;

\footnotetext{
${ }^{5}$ One cross correlation function presented death penalty support as a possible lead variable. Death penalty support preceded the number of death row inmates by three years, see Appendix 3, cross correlation number 3 . The additional 13 nonsignificant cross correlation functions are also provided in Appendix 3
} 
and number of The New York Times stories about the death penalty, about the fairness of the death penalty, or with anti-death penalty tones.

Figure 1 provides the cross-correlation function between the number of death penalty songs and support for the death penality. As shown, the number of songs "leads" death penalty support by two years denoting that the number of death penalty songs in one year is related significantly to death penalty support two years later. The negative correlation means that increases in the number of death penalty songs were associated with decreases in death penalty support. Neither the tone of the songs nor their popularity was found to be associated as either lead or lag variables with death penalty support (see Appendix 3, numbers 1 and 2).

Looking next at justice system activities related to capital punishment, only the number of executions was found to significantly lead death penalty support as shown in Figure 2. Similar to the association observed with number of death penalty songs, the number of executions negatively "leads" death penalty support; in this instance, by one year. In other words, a reduction in the number of executions was associated with an increase in death penalty support one year later. The cross-correlation function between the number of death row inmates and death penalty support produced the sole instance where support signficantly lead any of the candidate predictor variables (see Appendix 3, number
3). In that instance, death penalty support positively lead the number of death penalty inmates by three years. That is, as death penalty support increased, the number of death penalty inmates increased three years later. The other two measured capital punishment justice system activities, the number of death penalty sentences and the number of exonerations, were not correlated with death penalty support (see Appendix 3, numbers 4 and 5).

Looking next at crime levels, the number of violent crimes "leads" death penalty support by two years (see Figure 3 ), and the violent crime rate leads death penalty support by two and three years (see Figure 4). Both variables display positive lead correlations so that when violent crime increases in numbers and rate, death penalty support increases two years later (and three years later for rate).

In a comparable fashion, the number of murders positively leads death penalty support by two years (see Figure 5). When homicides increase, death penalty support increases two years later. Shifts in the murder rate were just short of significance (see Appendix 3, number 6). Property crime numbers and rates were not associated with death penalty support (see Appendix 3, numbers 7 and 8).

Lastly, the relationship between news coverage of capital punishment and death penalty support revealed three significant associations. The number of death

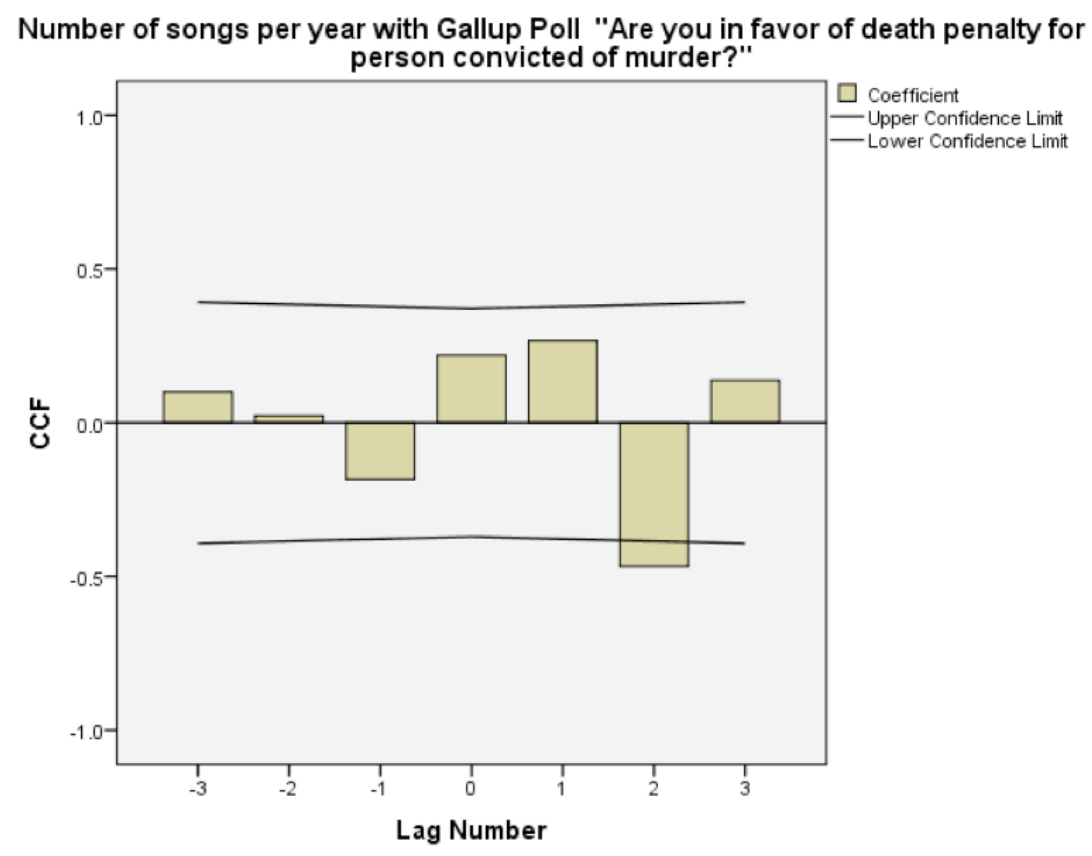

Figure 1: Cross-correlations between Number of Capital Punishment Songs and Death Penalty Support. 


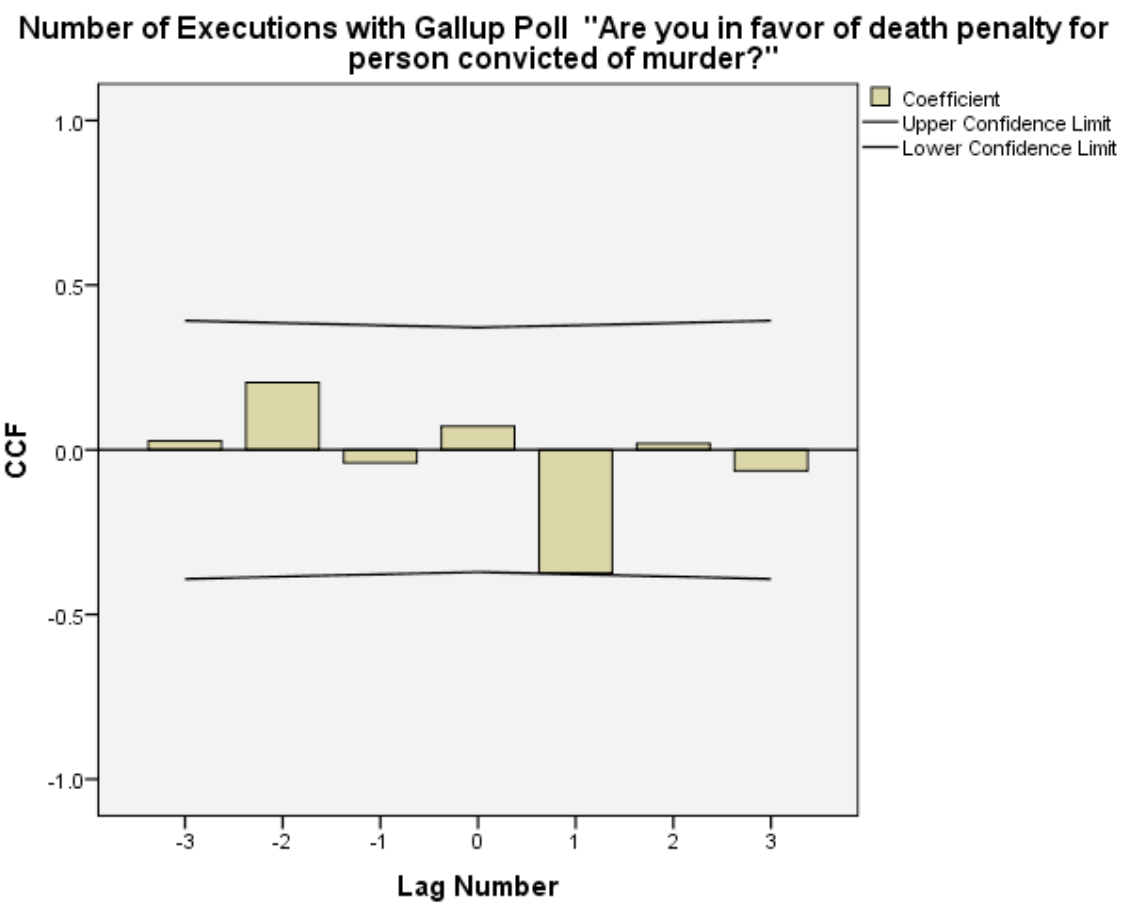

Figure 2: Cross-correlations between Number of Executions and Death Penalty Support.

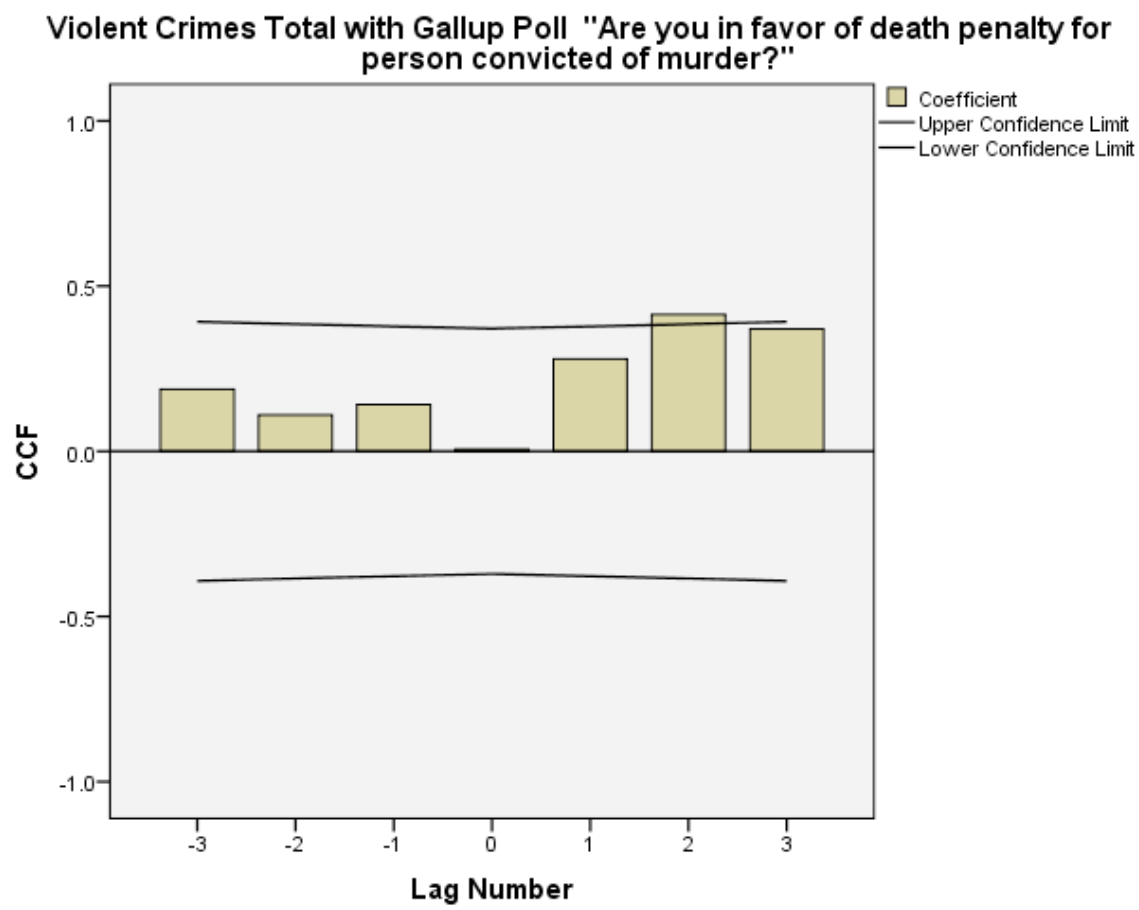

Figure 3: Cross-correlations between Number of Violent Crimes and Death Penalty Support.

penalty stories (Figure 6), the number of stories about fairness (Figure 7), and the number of stories assessed as anti-capital punishment (Figure 8) in The New York Times all were negatively correlated with death penalty support in the same year. In other words, increases in these types of stories were associated with same year decreases in death penalty support. The significant correlation with stories about the death penalty's fairness corroborates Baumgartner and his colleagues's argument about the "discovery of innocence."

The cross-correlation function with pro-death penalty stories just missed same year significance (see Appendix 3, number 9), while the number of front-page death penalty stories; stories about the efficiacy, 


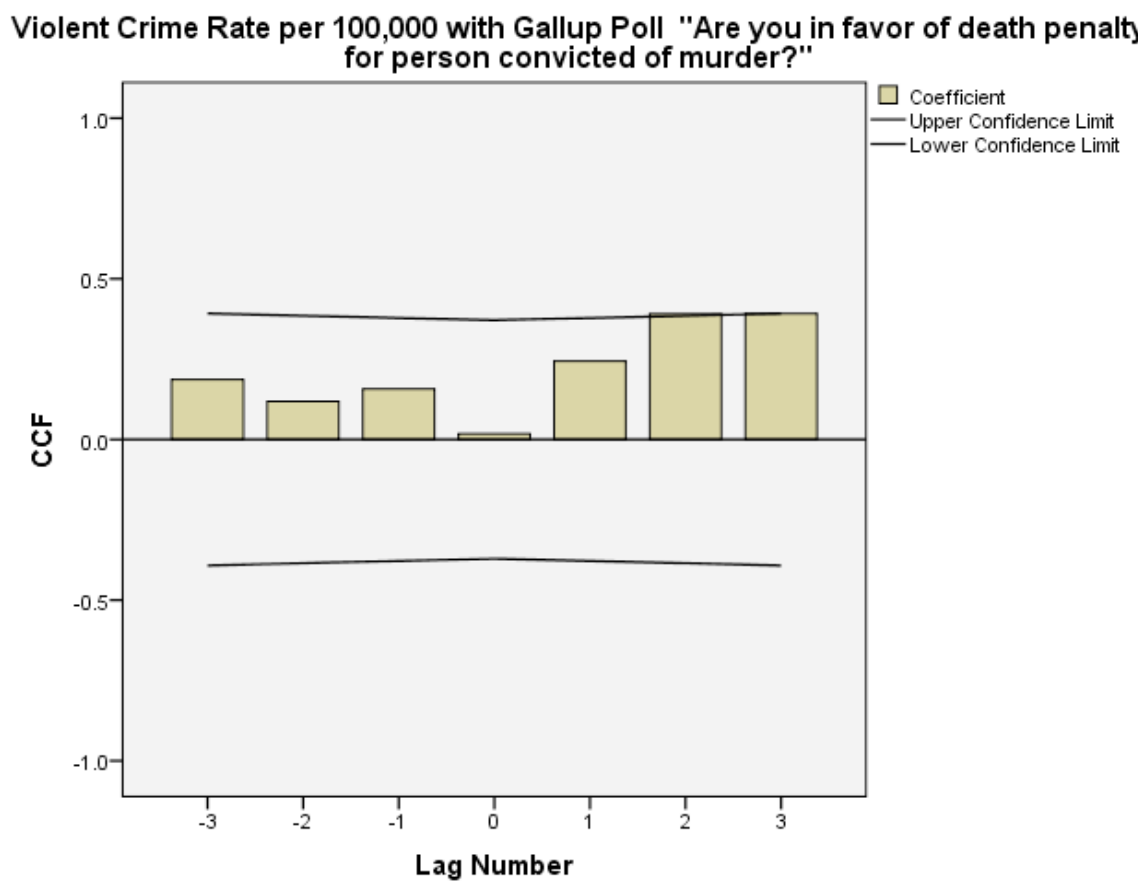

Figure 4: Cross-correlations between Violent Crime Rates and Death Penalty Support.

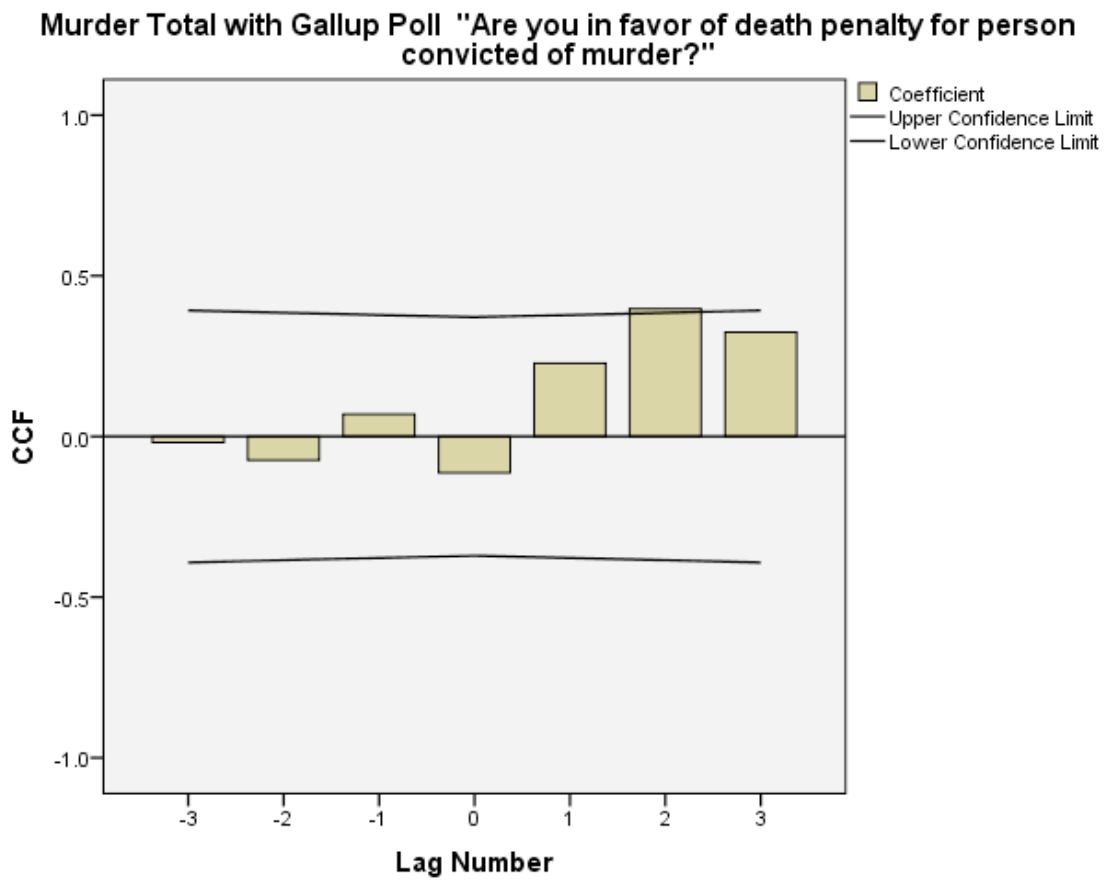

Figure 5: Cross-correlations between Number of Homicides and Death Penalty Support.

morality, or constitutionality of capital punishment; or the number of capital punishment stories in the Readers Guide were not significantly associated with death penalty support (see Appendix 3, numbers 10 through 14).

\section{Multivariate Analysis}

An additional research question of interest was which lead variables emerged as the better predictors of death penalty support. Because variables within similar conceptual areas were highly correlated with each other, the variable most strongly related to death penalty opinion from each conceptual area of death penalty music, news coverage of capital punishment, crime, and capital punishment-related justice activities was selected and included in a predictive multivariate analysis. Using a stepwise regression procedure, four independent variable series were regressed on the 


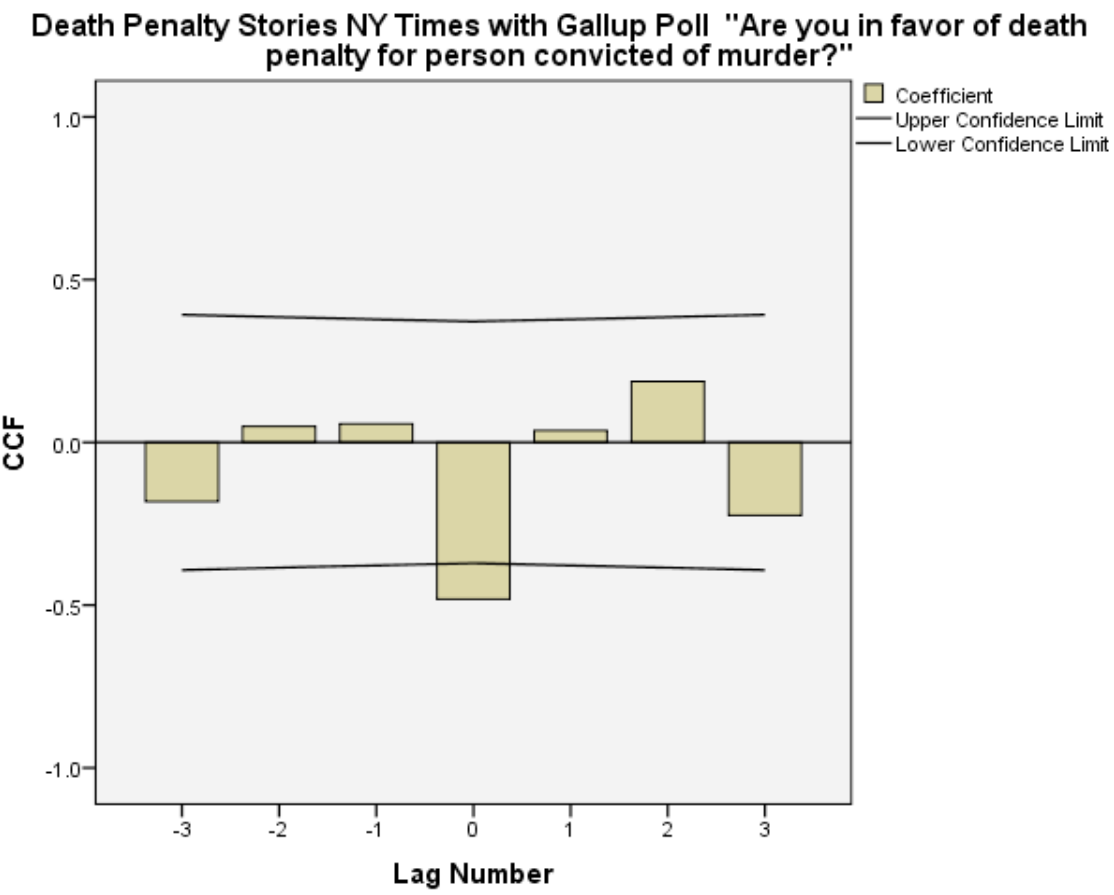

Figure 6: Cross-correlations between Number of Death Penalty Stories and Death Penalty Support.

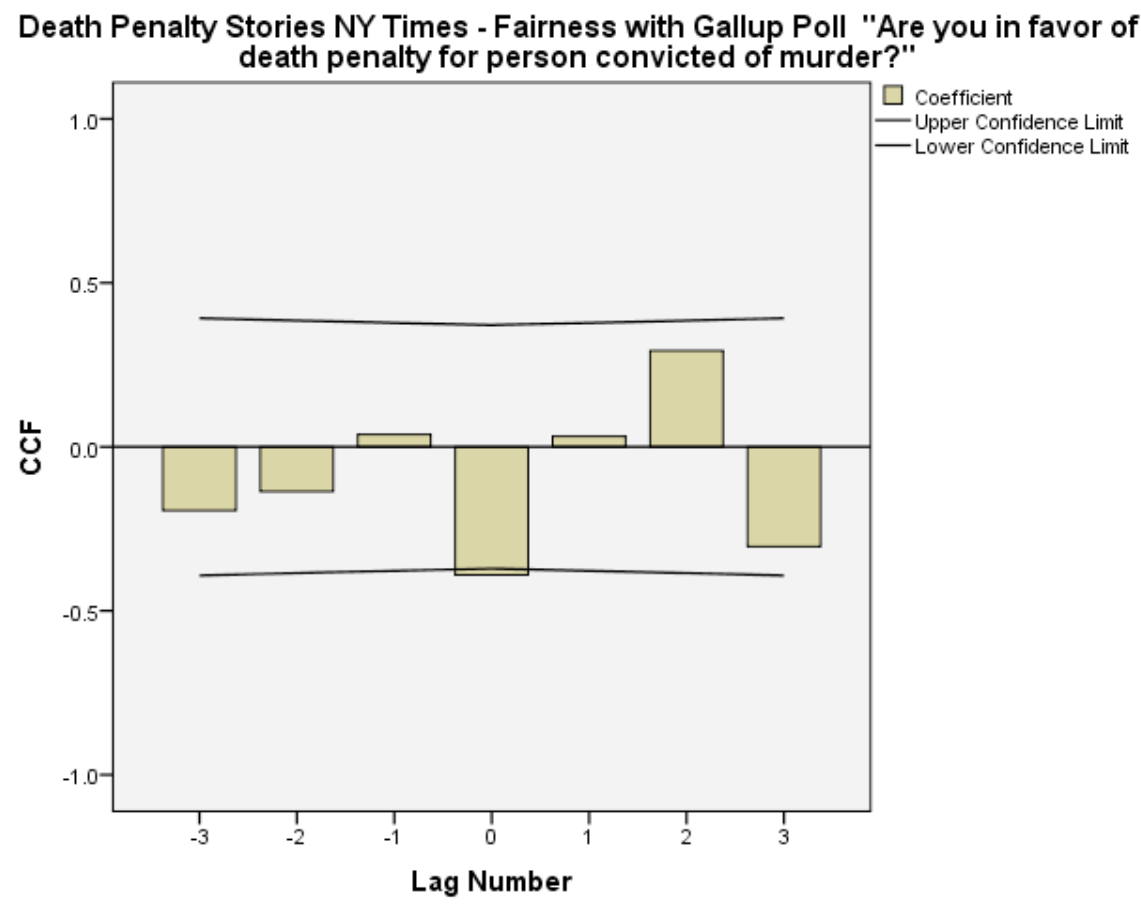

Figure 7: Cross-correlations between Number of Death Penalty Stories Focused on Fairness and Death Penalty Support.

dependent variable series. The independent variable series (in the order in which they entered into the final model) were: (1) number of death penalty songs-2year lead; (2) total number of murders-2-year lead; (3) number of executions-1-year lead; and (4) number of death penalty stories in The New York Times dealing with fairness-in the same years. Output from the regression is provided in Table 1. As shown, only two of the variable series were significantly predictive of the dependent variable series. The number of death penalty songs and the number of murders two years prior emerged as the best predictors of death penalty support. As found in the cross-correlation analysis, the number of death penalty songs in one year was inversely related to death penalty support two years later, and the total number of murders in one year was 


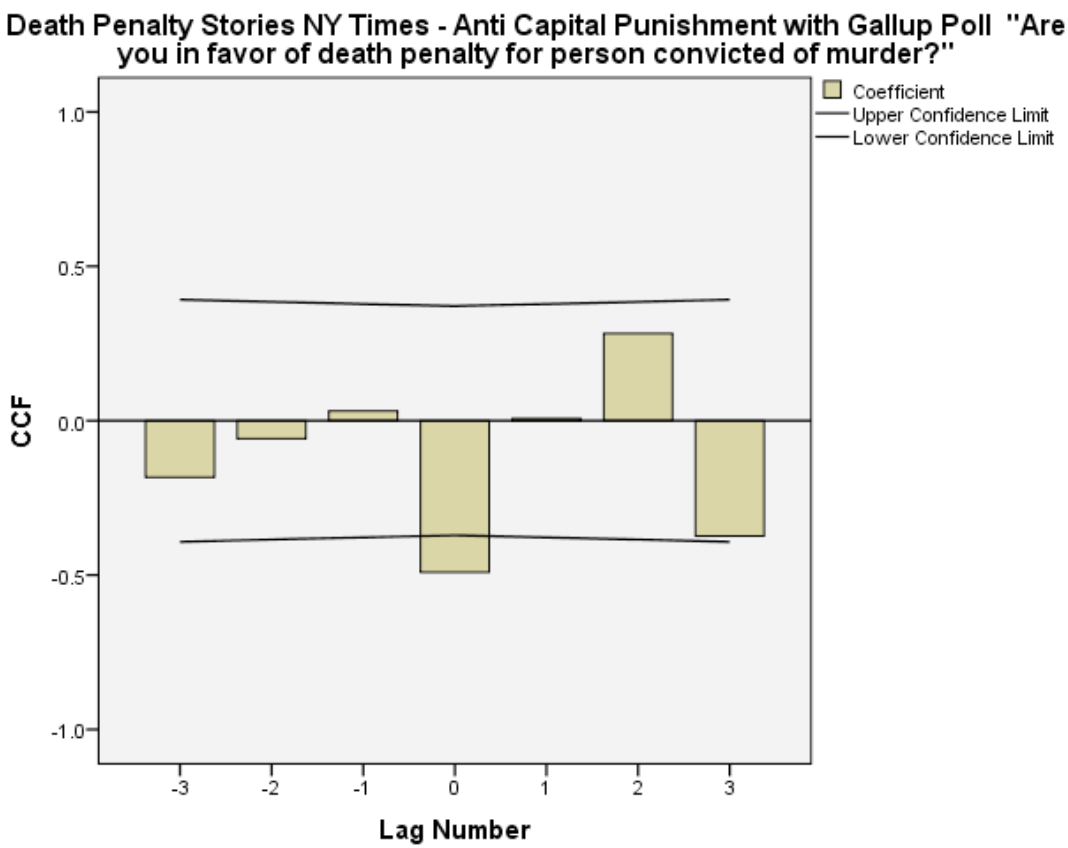

Figure 8: Cross-correlations between Number of Anti-Capital Punishment Stories and Death Penalty Support.

Table 1: Regression Results $(\mathrm{n}=27)$

\begin{tabular}{|c|c|c|c|c|c|c|c|}
\hline Final Model (step 2) & B & Std. Error & Beta & $\mathbf{t}$ & Sig. & Tolerance & VIF \\
\hline Constant & .002 & .004 & & .518 & .609 & & \\
\hline Murder (2 year lead) & .00000856 & .000 & .428 & 2.731 & .012 & .998 & 1.002 \\
\hline Execution Songs (2 year lead) & -.004 & .001 & -.500 & -3.188 & .004 & .998 & 1.002 \\
\hline Executions ( 1 year lead) & & & -.113 & -.635 & .532 & .791 & 1.264 \\
\hline Fairness (same year) & & & -.119 & -.579 & .568 & .600 & 1.666 \\
\hline \multicolumn{8}{|l|}{ Final Model Summary Statistics } \\
\hline \multicolumn{8}{|c|}{$F=8.404(p=.002), R^{2}=.412, R^{2}$ Change $=.183$, Durbin Watson $=1.67$} \\
\hline
\end{tabular}

positively related to death penalty support two years later. In other words, as the number of death penalty songs in one year increased, death penalty support two years later decreased, and as the total number of murders in one year increased, death penalty support two years later also increased. Because of the collinearity problem mentioned earlier, the total number of violent crimes series or the violent crime rate series could be substituted for the total number of murders series with little difference. ${ }^{6}$ The final two-variable

\footnotetext{
${ }^{6}$ An OLS regression employing the same four predictor variables produced substantially similar results with an $\mathrm{R}^{2}=.43$ and death penalty songs and number of murders emerging as the more predictive variables but with the number of murders with a higher beta value than the number of death penalty songs.
}

model explained 41 percent of the variation in the dependent variable.

The other two variables in the model-the number of executions (1-year lead) and the number of death penalty stories in The New York Times dealing with fairness (in the same years)-were not statistically significant. Because Baumgartner et al. found that the number of death penalty stories in The New York Times dealing with fairness was statistically significant and predicted death penalty opinion change, we tested another model in which the independent variables were entered in this order: (1) The New York Times' stories, (2) executions, (3) murders, and (4) songs. Results were the same as with the first stepwise procedure. 
Thus, unlike Baumgartner et al., the number of death penalty stories in The New York Times dealing with fairness was not statistically significant in this study, but the total number of murders (2-year lead) and the number of death penalty songs (2-year lead) were.

\section{DISCUSSION AND CONCLUSION}

Results of this study support the hypotheses that public consciousness about the death penalty as well as changes in aggregate death penalty opinion are associated with the content of popular media in the form of death penalty songs. As the number of death penalty songs increases in a year, death penalty support decreases two years later. Findings also corroborate the findings of Baumgartner et al. that as the number of murders in one year decreases, death penalty support decreases two years later. However, this should not be taken to mean that the number of death penalty songs "causes" death penalty support to decrease. One reason is that the tone of death penalty songs, either pro-death penalty, anti-death penalty, or neutral, was not statistically related to death penalty support. A second reason is that many songs, such as punk rock or rap songs, appeal to a relatively narrow demographic. Therefore, many people probably do not hear those songs or, if they do hear them, probably ignore the lyrics. It is speculated that popular songwriters' attention to the death penalty as a lyrical subject reflects the media's attention to the death penalty as well as other social events and the level of social angst at any particular time. We also do not believe that the number of murders in a year "causes" death penalty support or opposition to vary two years later. Rather a more plausible explanation for both findings is that the variables are contextual. We surmise that largely through a narrative persuasion model process rather than cognitive processing model processes, the number of death penalty songs and death penalty opinion (as well as additional unmeasured social factors) reflect the prevailing social and political climate and, together with the number of murders, as Bohm suggested, the level of dread and angst in a society. ${ }^{7}$

No doubt a small percentage of people, through a cognitive processing model mechanism, are persuaded by evidence of the death penalty's flaws, such as the conviction and execution of the innocent, and the exorbitant costs of the penalty in relation to alternatives, but for most people the evidence, but perhaps not the music, falls on deaf ears. ${ }^{8}$ In the main, neither the lyrics, the melody, the genre, or the popularity of death penalty songs makes a difference in changing aggregate death penalty opinion. What seems to matter is that the death penalty song was written in the first place; that the song's subject is the death penalty. In other words, aggregate death penalty opinion changes when the social and political climate is right, and the popular media, it appears, signals when that is.

\footnotetext{
${ }^{7}$ Of course, as is the case with all research that examines potential relationships, the statistically significant relationships found in this study may be spurious.

${ }^{8}$ We conservatively estimate that about 40 percent of the American public could be persuaded to change their death penalty opinion (the difference between the 80 percent of aggregate death penalty support in a 1994 poll and the 42 percent in a 1966 poll). That means that about 60 percent of the American public cannot be persuaded to change their opinion. If the 60 percent of the public resistant to change were divided evenly: 30 percent in support of the death penalty and 30 percent in opposition to it, then, as Bruck (cited in Haines, 1996: 164) had predicted, it only would be necessary to convince a quarter to a third of death penalty proponents to oppose the penalty to effectively neutralize the death penalty's "political potency."
}

\section{APPENDIX}

Appendix 1: $\quad$ Popular Songs about Capital Punishment, 1976-2008

\begin{tabular}{|c|c|c|c|c|c|}
\hline Song & Artist & Year & Genre & Top 100 & Tone \\
\hline Annie Christian & Prince & 1981 & Pop/Funk & $\mathrm{N}$ & For \\
\hline Burning A Sinner & Witchfinder General & 1982 & Metal & $\mathrm{N}$ & For \\
\hline Ride The Lightning & Metallica & 1984 & Rock & Y/Album & Against \\
\hline Sunset Blvd & Isley/Jasper/Isley & 1985 & $R \& B$ & Y/Album & For \\
\hline The Eliminator & Agnostic Front & 1986 & Rock & $\mathrm{N}$ & For \\
\hline Electrocution & Sodom & 1987 & Rock & $\mathrm{N}$ & For \\
\hline Annihilation Complete & Anacrusis & 1988 & Metal & $\mathrm{N}$ & Against \\
\hline Drama & Ice-T & 1988 & Rap & Y/Album & For \\
\hline Let Him Dangle & Elvis Costello & 1989 & Soft Rock & Y/Album & For \\
\hline
\end{tabular}




\begin{tabular}{|c|c|c|c|c|c|}
\hline Last Act of Defiance & Exodus & 1989 & Metal & $\mathrm{N}$ & Against \\
\hline You Played Yourself & Ice-T & 1989 & Rap & Y/Album & For \\
\hline Reduce to Ashes & Pestilence & 1989 & Rock & $\mathrm{N}$ & Against \\
\hline Midnight On the Murder Mile & $\begin{array}{c}\text { Carter : Unstoppable Sex } \\
\text { Machine }\end{array}$ & 1991 & Alternative Rock & $\mathrm{N}$ & For \\
\hline Pulse of the Rhyme & Ice-T & 1991 & Rap & Y/Album & For \\
\hline The Just Law & Alastis & 1992 & Metal & $\mathrm{N}$ & Neutral \\
\hline Fatadical Date & Alastis & 1992 & Metal & $\mathrm{N}$ & For \\
\hline No Sunshine & Kid Frost & 1992 & Rap & Y/Album/Song & Neutral \\
\hline Archives of Pain & Manic Street Preachers & 1994 & Alternative Rock & $\mathrm{N}$ & For \\
\hline The Snake With Eyes of Garnet & $\begin{array}{c}\text { Shane Macgowan And } \\
\text { The Popes }\end{array}$ & 1994 & Alternative Rock & Y/Album & For \\
\hline Death Be the Penalty & Shabazz the Disciple & 1995 & $R \& B$ & Y/Single & Against \\
\hline Death Row & Accept & 1995 & Metal & $\mathrm{N}$ & Against \\
\hline Down '71 & Bone Thugs-N-Harmony & 1995 & Rap & Y/Album & For \\
\hline Shadowboxin' & Genius & 1995 & Rap & Y/Single & For \\
\hline Unseen Darkness & Sinister & 1995 & Metal & $\mathrm{N}$ & For \\
\hline Capital Punishment & Big Punisher & 1998 & Rap & $\mathrm{N}$ & Against \\
\hline Let The Killing Begin & Arch Enemy & 1998 & Metal & $\mathrm{N}$ & Neutral \\
\hline 2000 Volts & Big Bad Voodoo Daddy & 1998 & Alternative Rock & Y/Album & Neutral \\
\hline Hang the Bastard & Trey Parker & 1998 & Musical & $\mathrm{N}$ & For \\
\hline Buckingham Palace & Canibus & 1998 & Rap & $\mathrm{N}$ & For \\
\hline Overseers & Earth Crisis & 1998 & Metal & $\mathrm{N}$ & Against \\
\hline Greeny Green & Goodie Mob & 1998 & Rap & Y/Album & For \\
\hline Steel Bar Blues & Bret Michaels & 1998 & Metal & $\mathrm{N}$ & Against \\
\hline A Letter From Death Row & Bret Michaels & 1998 & Metal & $\mathrm{N}$ & For \\
\hline No Success & Atari Teenage Riot & 1999 & Electronic/Dance & Y/Album & Against \\
\hline Sacco and Vanzetti & Against All Authority & 2001 & Rock & $\mathrm{N}$ & Against \\
\hline A Fury Divine & Amon Amarth & 2001 & Metal & $\mathrm{N}$ & Against \\
\hline If Only... & Anasarca & 2001 & Rock & $\mathrm{N}$ & Neutral \\
\hline Resolution & Antiskeptic & 2001 & Pop & $\mathrm{N}$ & Against \\
\hline Whatcha Gonna Do & Big Punisher & 2001 & Rap & $\mathrm{N}$ & For \\
\hline Uncivilization & Biohazard & 2001 & Metal & $\mathrm{N}$ & Against \\
\hline
\end{tabular}




\begin{tabular}{|c|c|c|c|c|c|}
\hline Call Upon Your Gods & Dark Lotus & 2002 & Rock & $\mathrm{N}$ & For \\
\hline Insecurity Alert & No Use For A Name & 2002 & Rock & $\mathrm{N}$ & For \\
\hline La Haine & Asian Dub Foundation & 2003 & Alternative Rock & $\mathrm{N}$ & Against \\
\hline Dead End & Insane Clown Posse & 2003 & Rock & $\mathrm{N}$ & For \\
\hline Minus One & Jamie Notarthomas & 2003 & UNK & $\mathrm{N}$ & Against \\
\hline $\begin{array}{c}\text { You Know What They Do To Guys } \\
\text { Like Us In Prison }\end{array}$ & My Chemical Romance & 2004 & Punk Rock & $\mathrm{N}$ & For \\
\hline Waitin' 4 The Hair & Acid Drinkers & 2004 & Rock & $\mathrm{N}$ & Neutral \\
\hline We Are & Ana Johnson & 2004 & Rock/Alternative & $\mathrm{N}$ & Against \\
\hline $\begin{array}{c}\text { My First Kiss at the Public } \\
\text { Execution }\end{array}$ & The Blood Brothers & 2004 & Indie Rock & $\mathrm{N}$ & Neutral \\
\hline It's a Hit & Rilo Kiley & 2004 & Alternative Rock & $\mathrm{N}$ & Against \\
\hline Goddess (of The Sad Man) & Amorphis & 2005 & Rock & $\mathrm{N}$ & For \\
\hline I Am The Law & Anthrax & 2005 & Rock & $\mathrm{N}$ & For \\
\hline Punishment Fits The Crime & Ramones & 2005 & Rock & $\mathrm{N}$ & For \\
\hline I'm A Rocker & Acid Drinkers & 2006 & Rock & $\mathrm{N}$ & Neutral \\
\hline Violet Execution & Sebadoh & 2006 & Indie Rock & $\mathrm{N}$ & Neutral \\
\hline Execution & First Blood & 2006 & Hardcore/Punk & $\mathrm{N}$ & Against \\
\hline Fuel & Ani Difranco & 2007 & Folk & $\mathrm{N}$ & Against \\
\hline A Hard's Rain & Ann Wilson & 2007 & Rock & $\mathrm{N}$ & Neutral \\
\hline The Rack & Asphyx & 2007 & Rock & $\mathrm{N}$ & Against \\
\hline One Little Solider & Patrick Fitzgerald & 2007 & Punk Rock & $\mathrm{N}$ & For \\
\hline Tightly Wound & MXPX & 2007 & Rock & Y/Album & For \\
\hline
\end{tabular}

Note: The years 1976 to 1980 , and 2008 were searched with no capital punishment related songs uncovered.

\section{APPENDIX 2: CONTROL VARIABLES}

\section{(from Baumgartner et al., 2008 + Updated for 2007-08)}

The following are descriptions of the operationalization of the variables provided by Baumgartner and his colleagues of the dependent and predictive variables that were utilized in this study.

\section{Death Penalty Measures}

\section{Death Row Inmates}

The number of inmates on death row data series provides the total number of individuals under sentence of death in the United States in each year. Sources: Annual measure. 1976-2005 data from Snell, 2005, Figure 1; 2006 data from Fins, 2006; and 2007-08 data from the Death Penalty Information Center (DPIC).

\section{Death Sentences}

The number of death sentences imposed each year. Sources: 1976-2005 data from Snell, 2005, Appendix Table 2; 2006-08 data from the DPIC.

\section{Executions}

This series provides the number of individual executed in the United States in each year. Annual measure sources: 1976-2005 data from Snell, 2005, Figure 4; 2006-08 data from the DPIC.

\section{Exonerations}

The annual number of death row exonerations in the United States. Source: 1976-2008 data from the DPIC. 


\section{Crime Measures}

\section{The Number and the Rate of Violent Crimes, Property Crimes, and Homicides}

The number and the rate of violent crimes, property crimes, and homicides committed each year in the United States were extracted mainly from the Uniform Crime Reporting Program associated tables "Crime in the United States by Volume and Rate per 100,000 Inhabitants" supplemented from James Fox and Marianne Zawitz (2006) "Homicide Trends in the United States," Bureau of Justice Statistics.

\section{Media Measures}

\section{The New York Times Capital Punishment Coverage}

Baumgartner et al. describe the tracking of how capital punishment was framed in The New York Times as the collection of all abstracts of articles on the death penalty listed under the heading "capital punishment." A total of 3,939 abstracts were reviewed and coded regarding the tone of the article and its component arguments regarding capital punishment. Tone is described as "the direction or implication of an article" and was coded as pro-death penalty, anti-death penalty, or neutral (Baumgartner et al, 2008, p. 243-244). From this process, they generated the following time series:

1. The number of The New York Times death penalty stories

2. Front-page death penalty stories

3. Death penalty efficacy stories

4. Morality stories

5. Fairness stories

6. Constitutionality stories

7. Pro-death penalty and anti-death penalty stories.

\section{APPENDIX 3: ADDITIONAL CROSS CORRELATIONS}

\section{Song Tone}

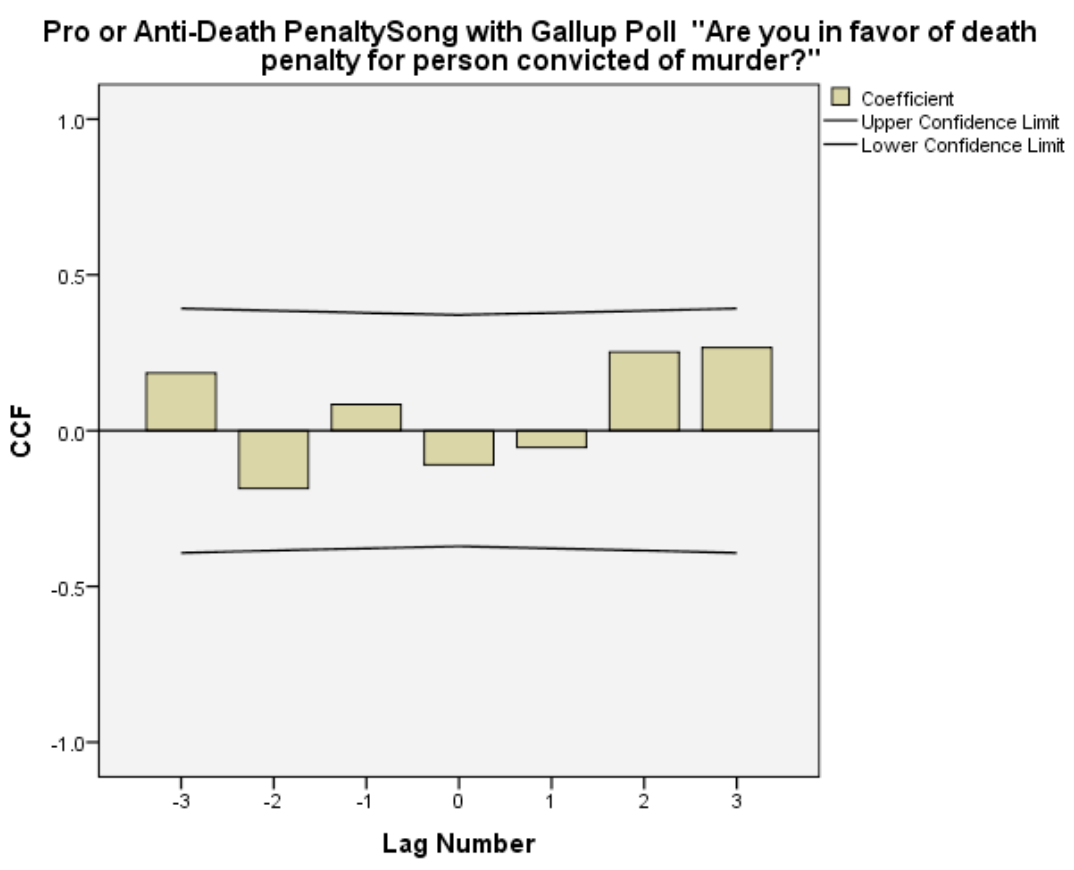




\section{Song Popularity}

Pro or Anti-Death Penalty Combined with Popularity with Gallup Poll "Are you in favor of death penalty for person convicted of murder?"

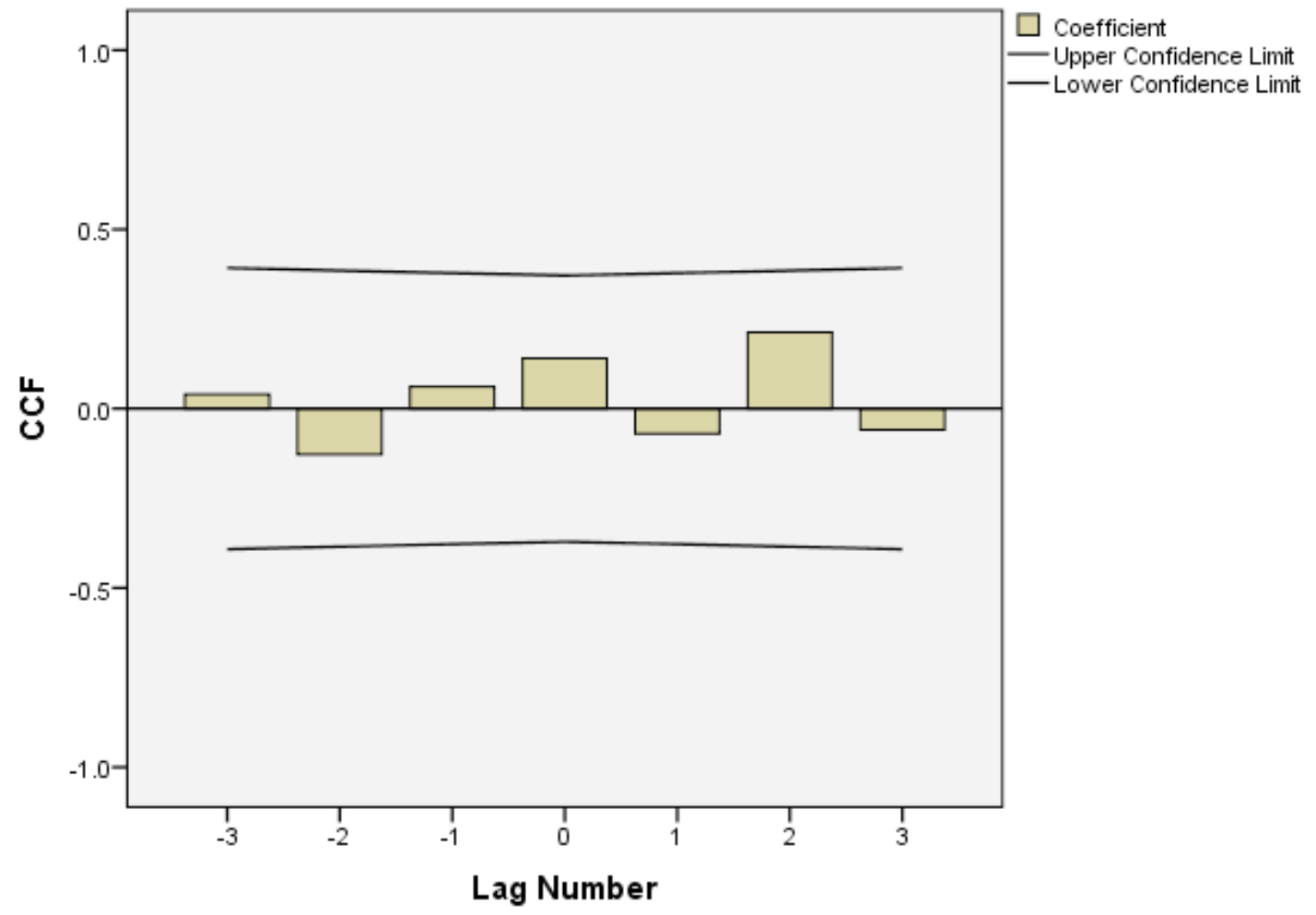

3. Death Row Inmates

Number of Deathrow Inmates with Gallup Poll "Are you in favor of death penalty for person convicted of murder?"

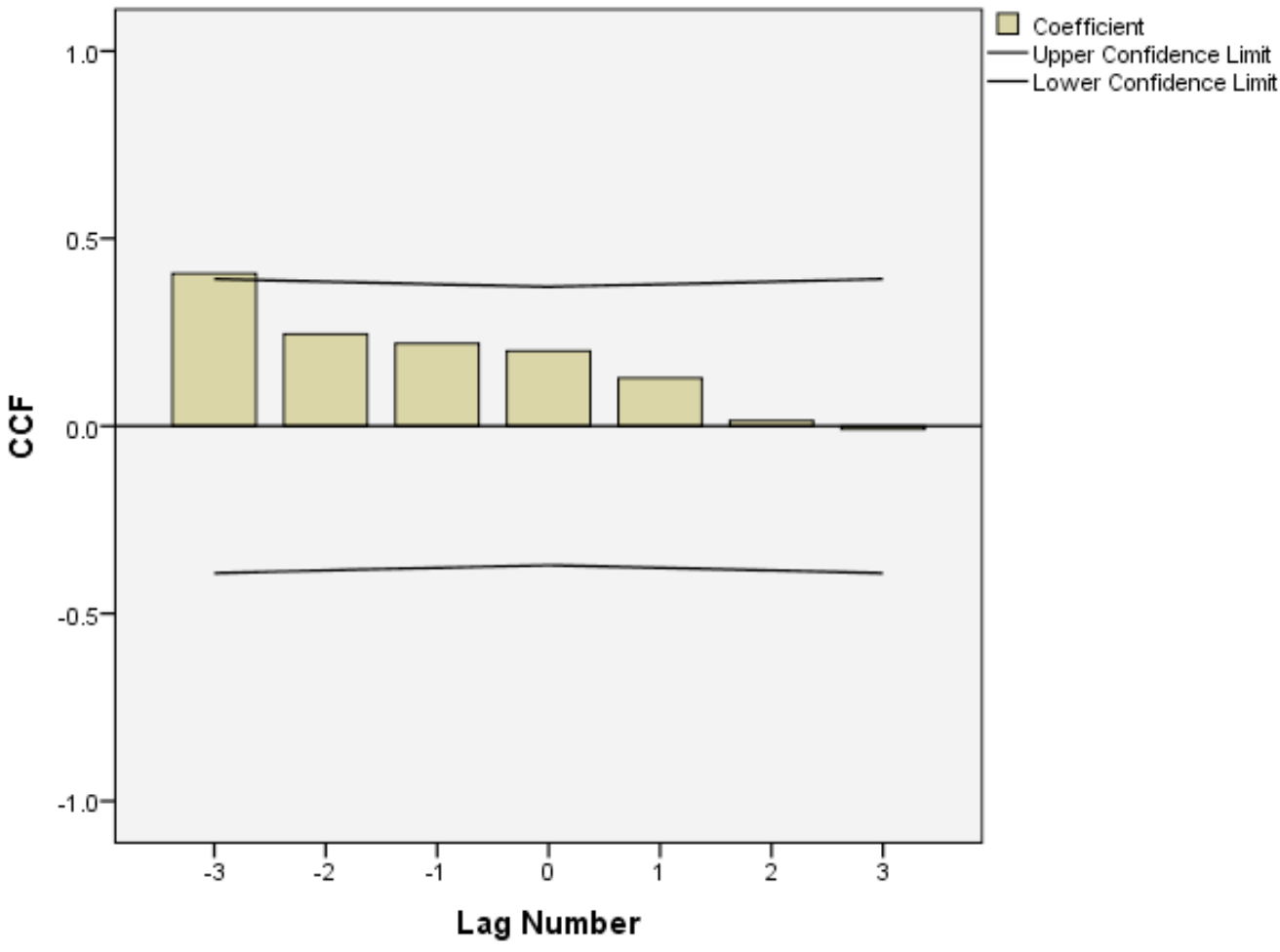




\section{Death Penalty Sentences}

Number of Death Penalty Sentences with Gallup Poll "Are you in favor of death penalty for person convicted of murder?"

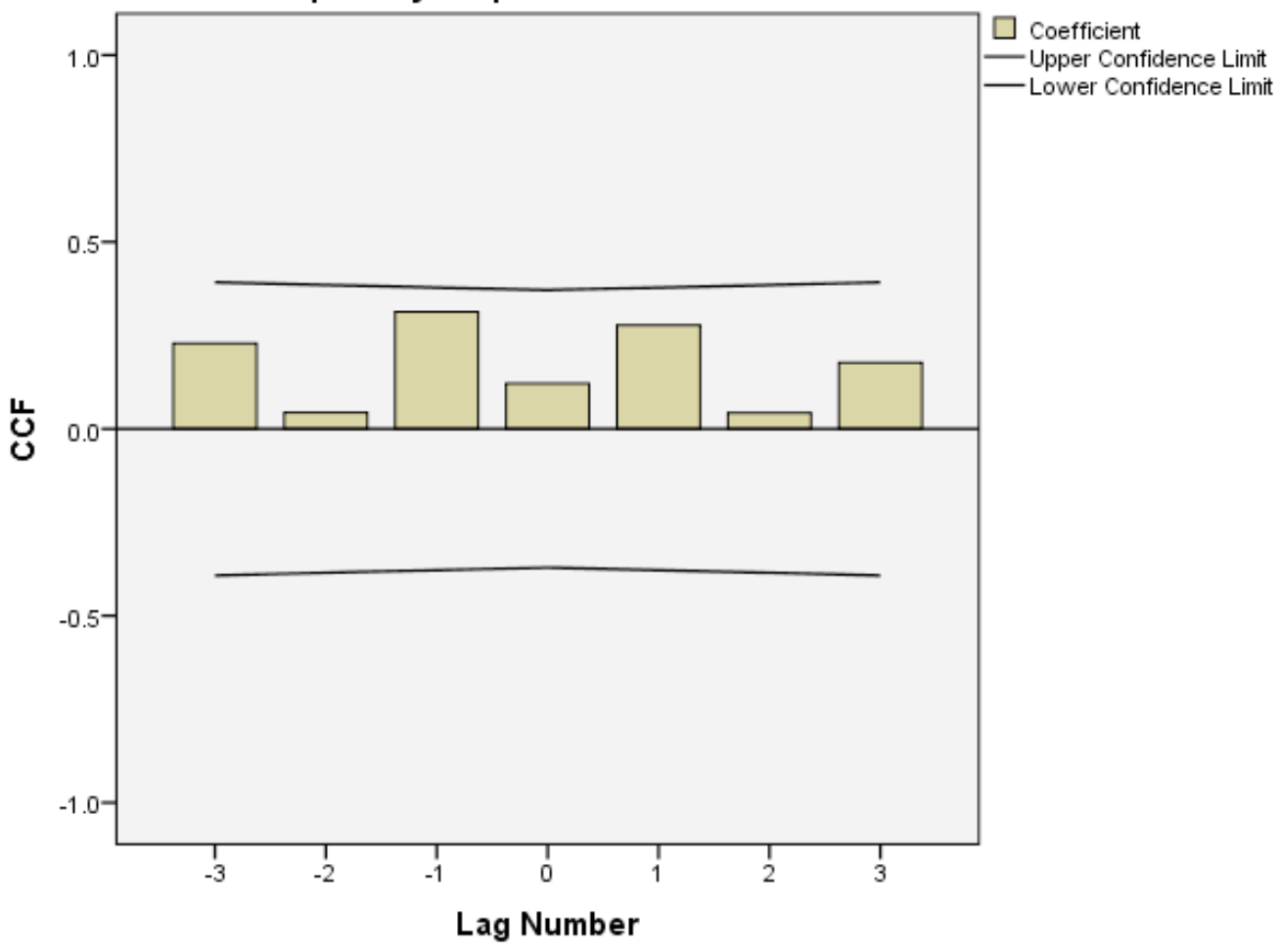

\section{Exonerations}

Number of Exonerations with Gallup Poll "Are you in favor of death penalty for person convicted of murder?"

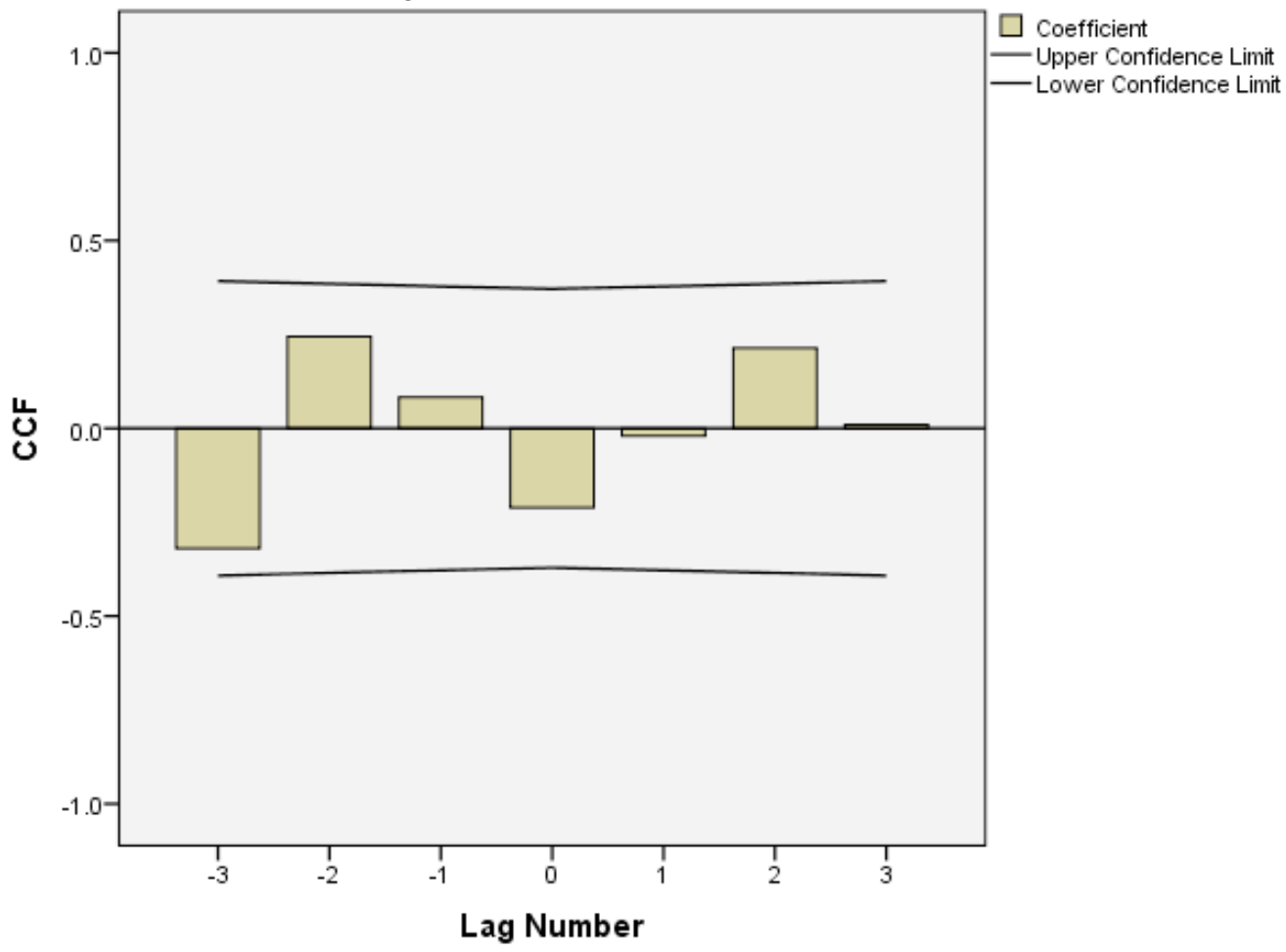




\section{Murder Rate}

Murder Rate per 100,000 with Gallup Poll "Are you in favor of death penalty for person convicted of murder?"

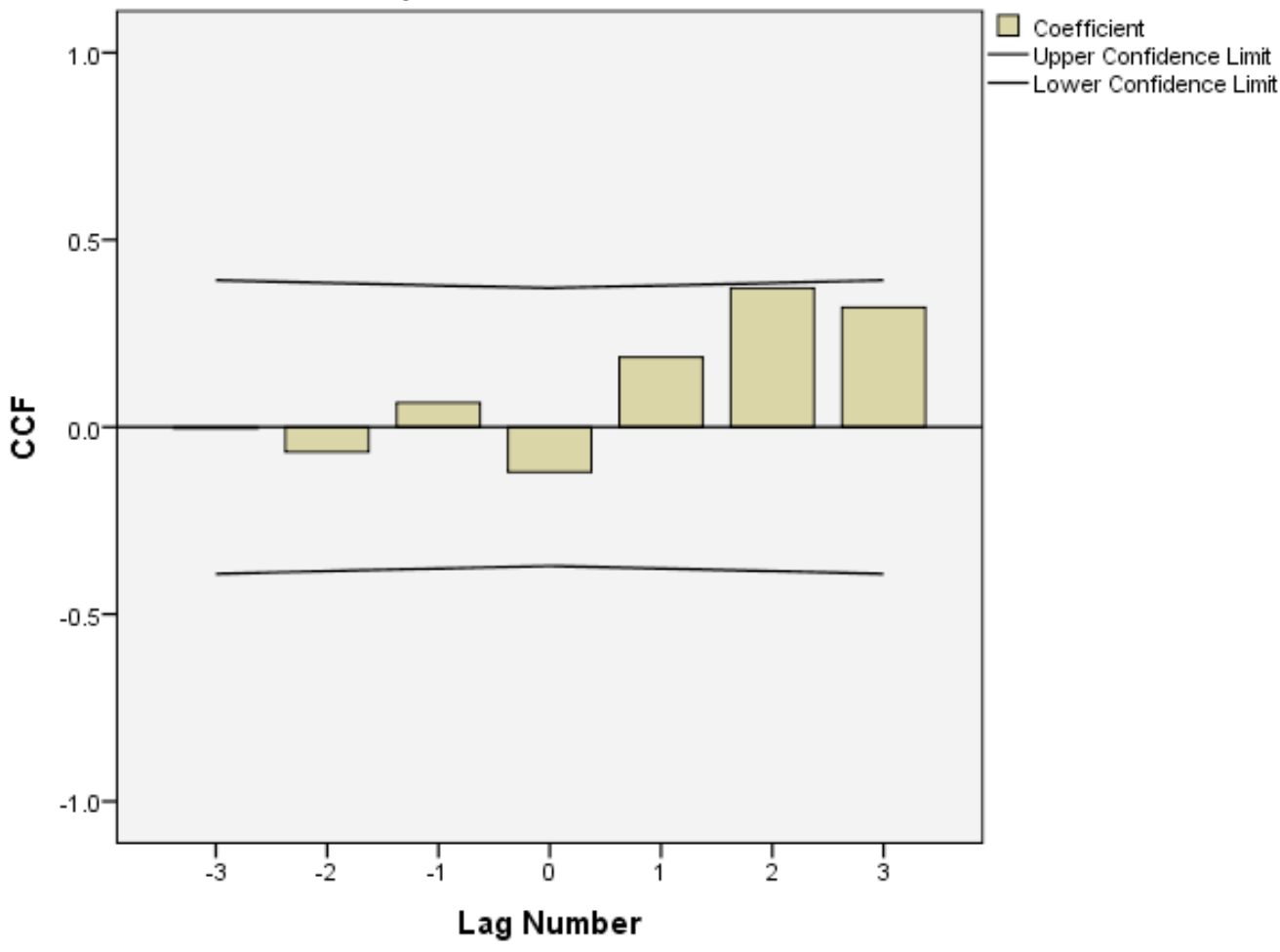

\section{Property Crime}

Property Crime Total with Gallup Poll "Are you in favor of death penalty for person convicted of murder?"

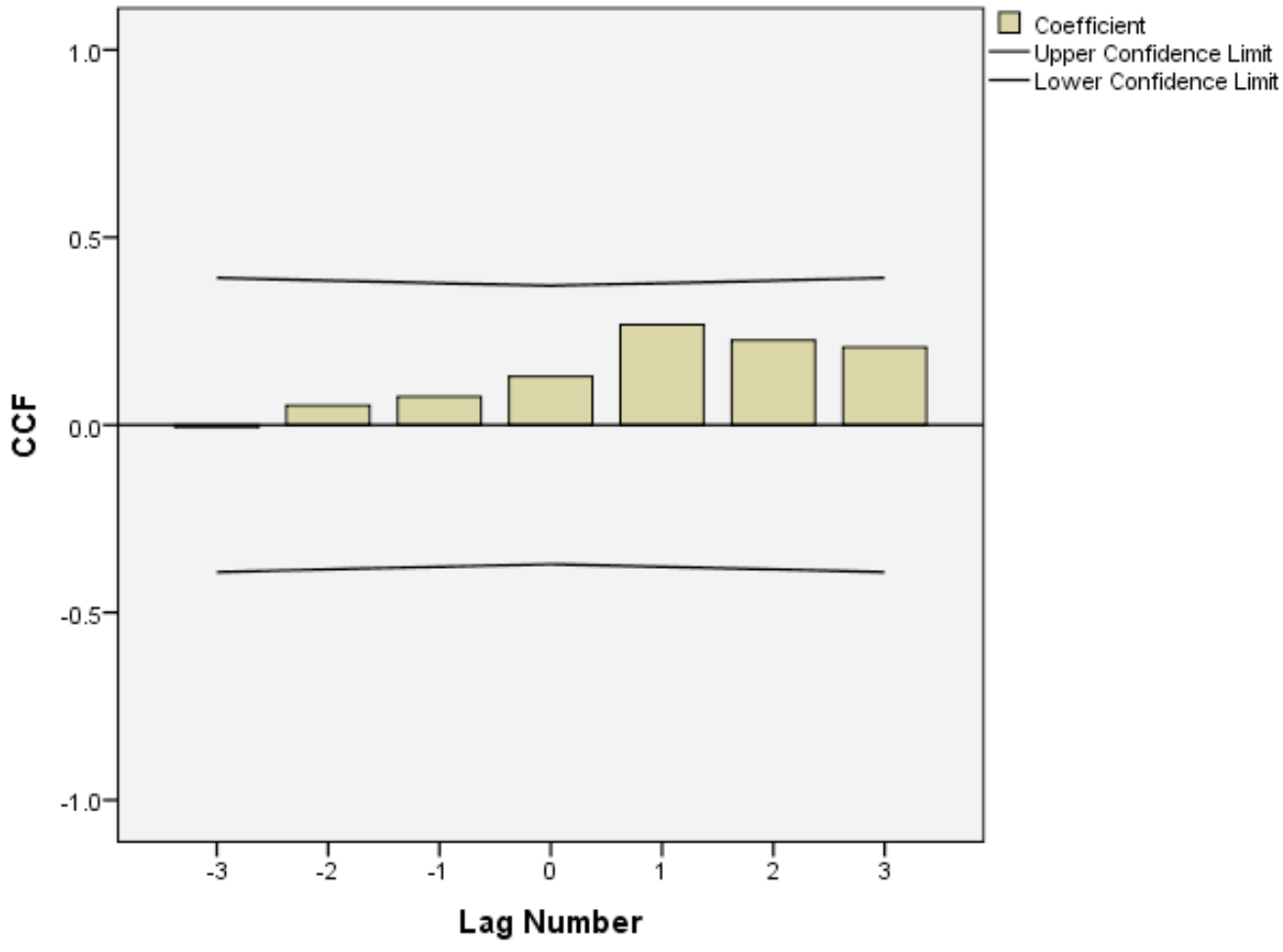




\section{Property Crime Rate}

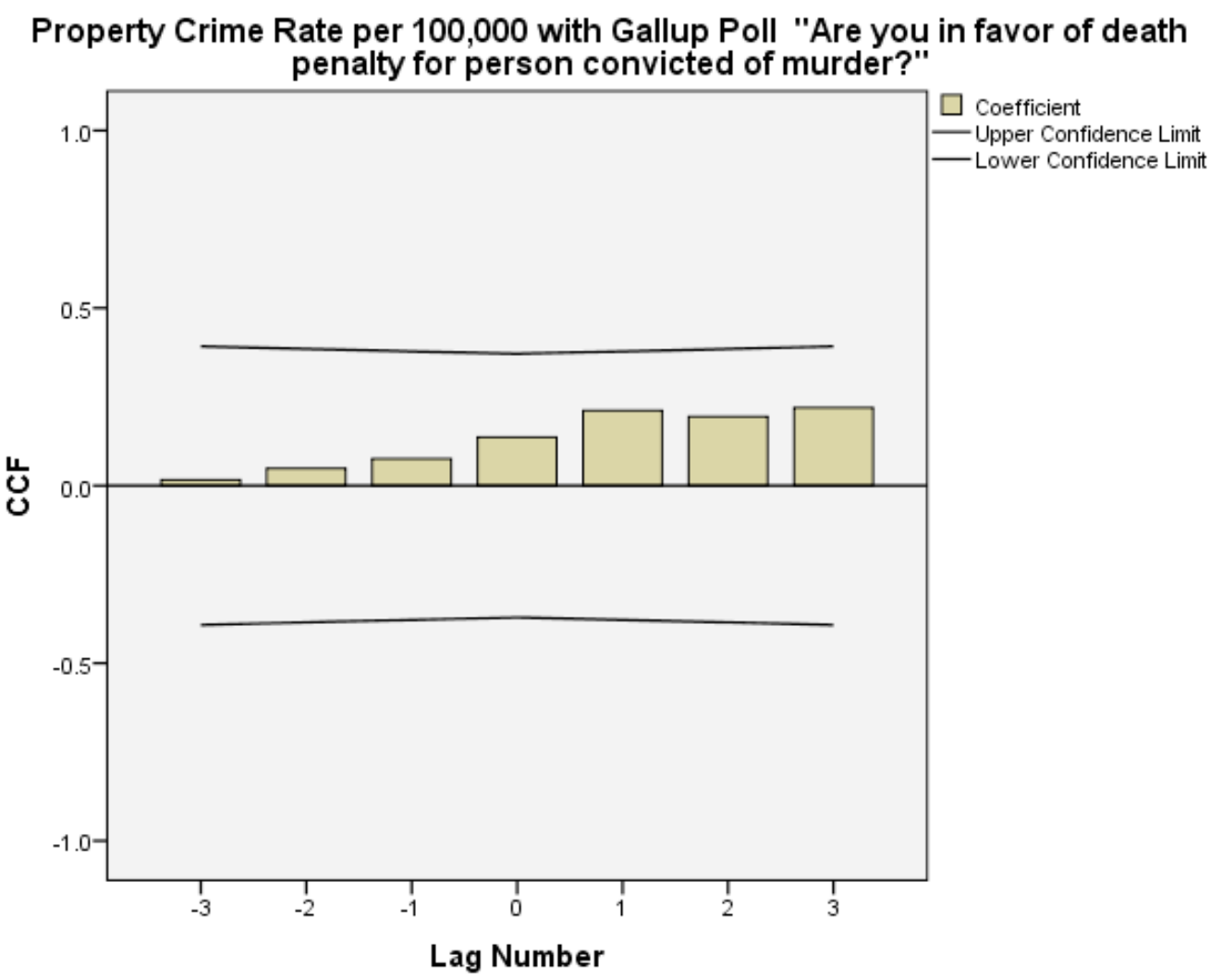

\section{Pro Capital Punishment Stories}

Death Penalty Stories NY times - Pro Capital Punishment with with Gallup Poll "Are you in favor of death penalty for person convicted of murder?"

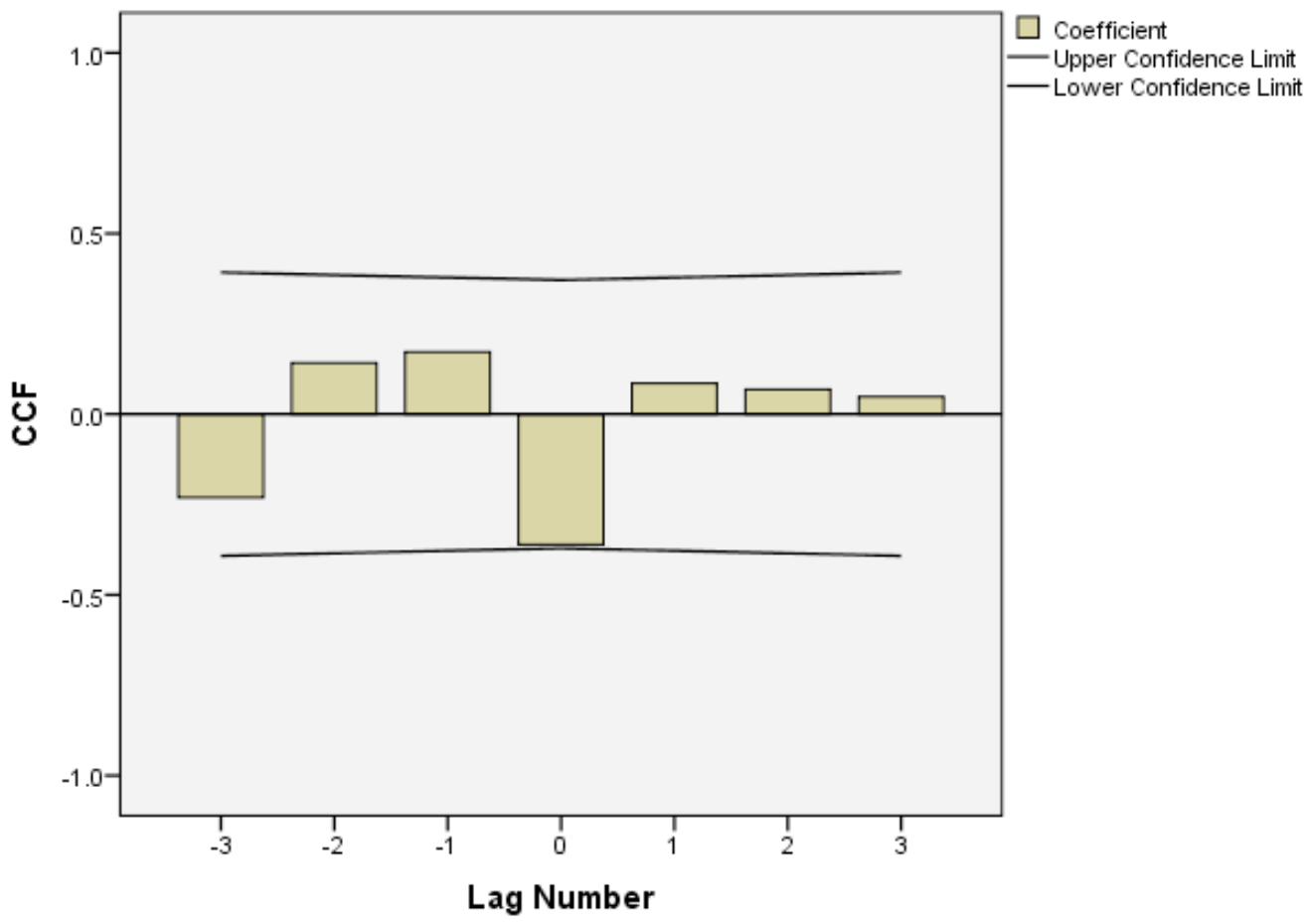




\section{Front Page Stories}

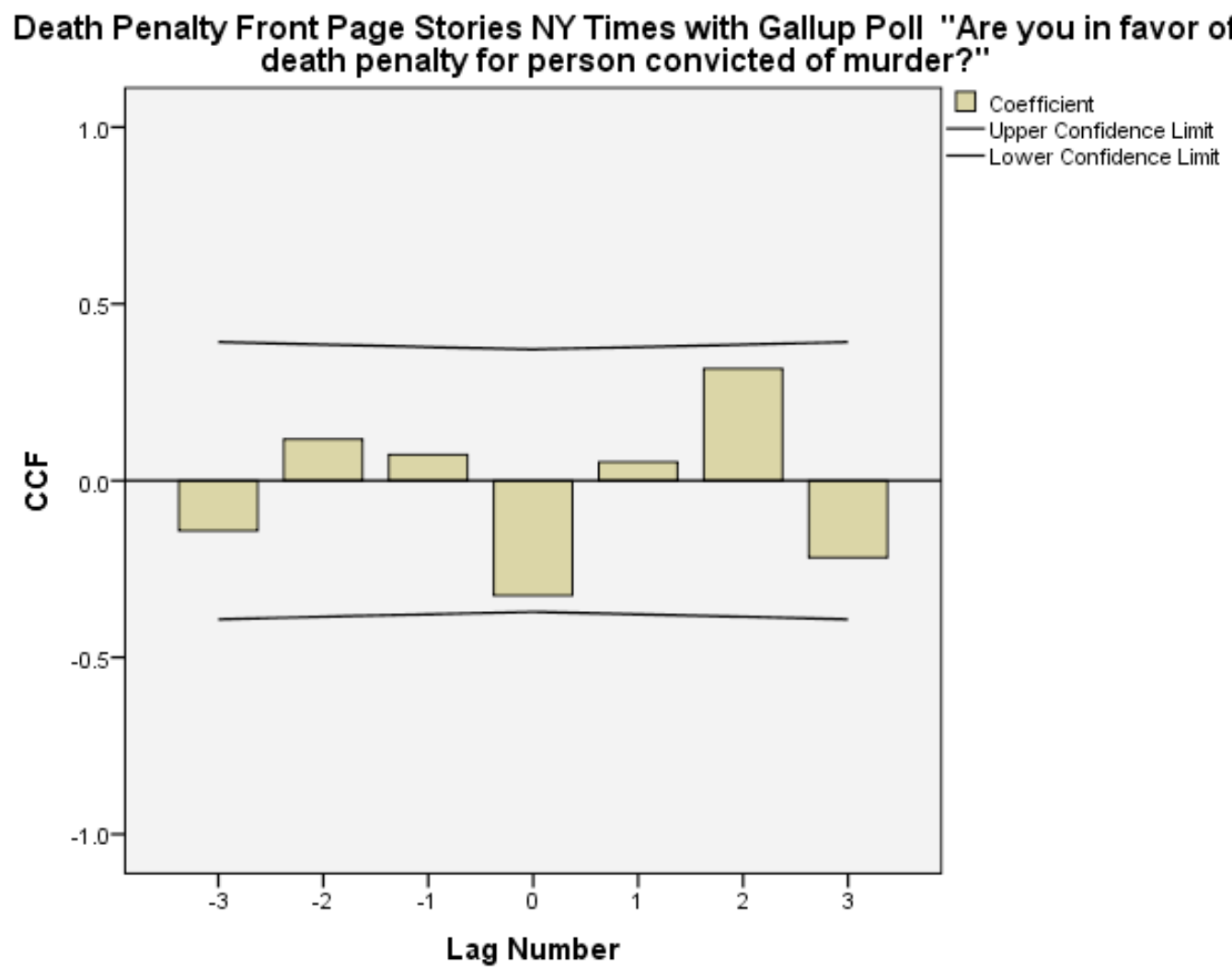

\section{Efficacy Stories}

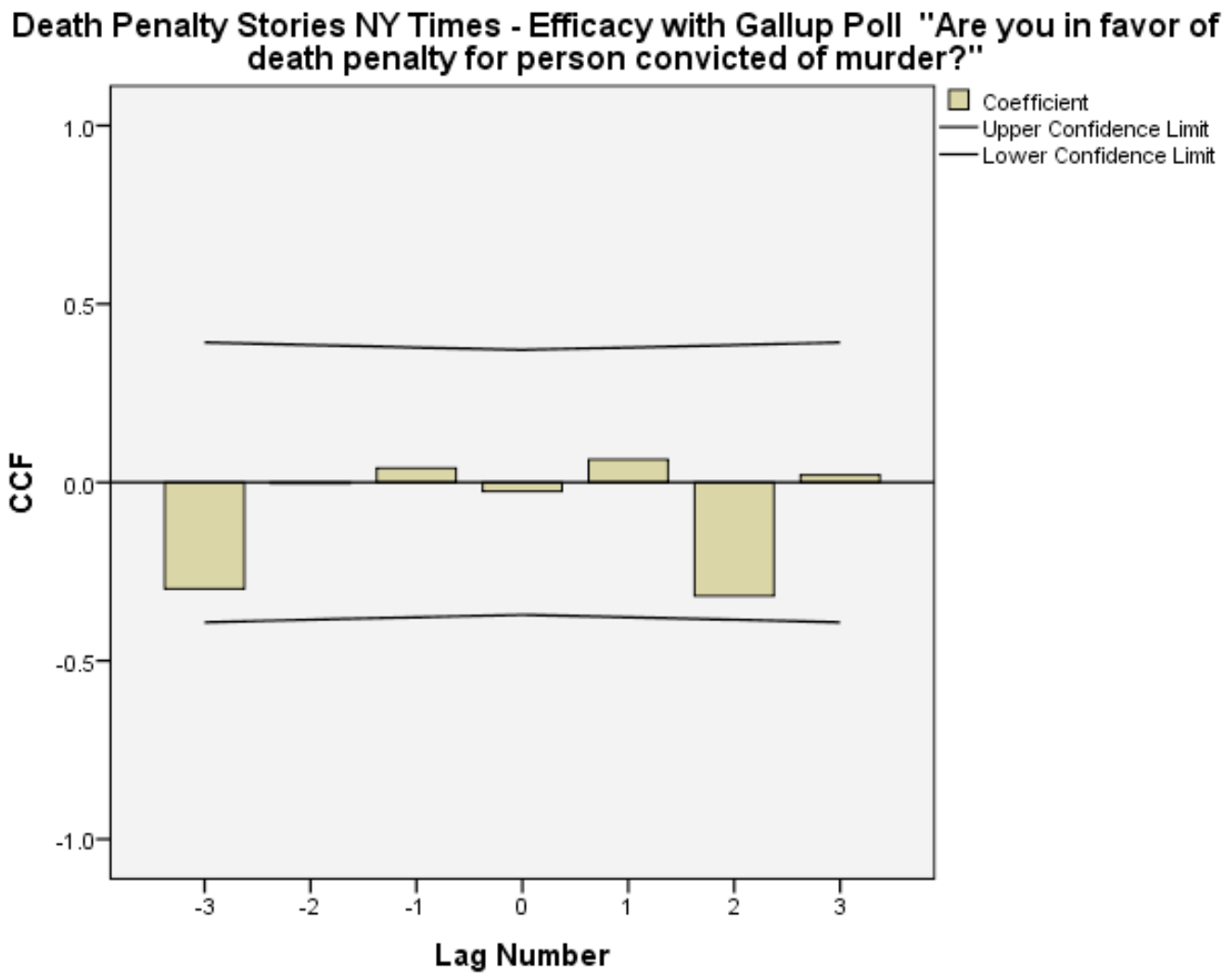




\section{Morality Stories}

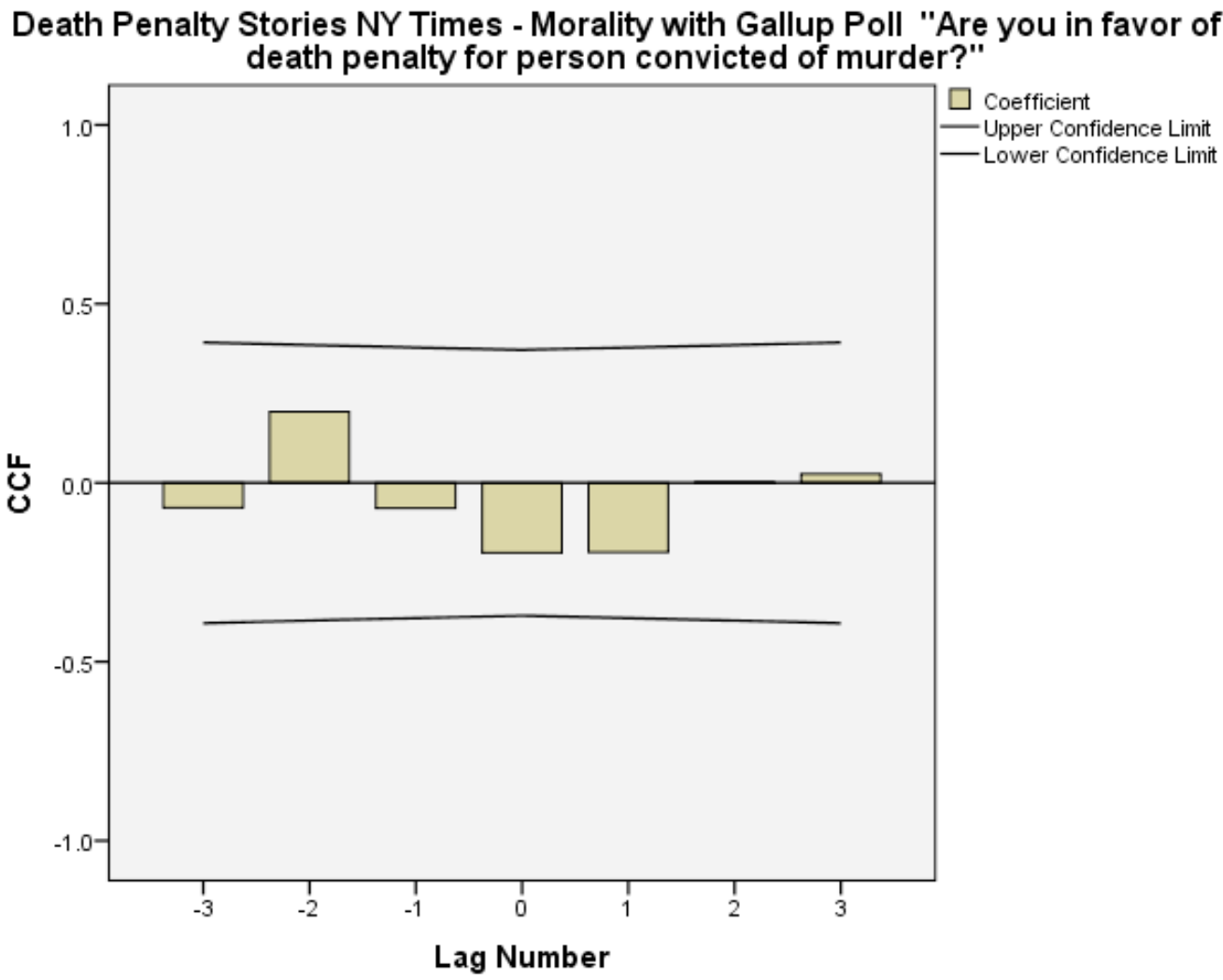

13. Constitutionality Stories

Death Penalty Stories NY times - Constitutionality with Gallup Poll "Are you in favor of death penalty for person convicted of murder?"

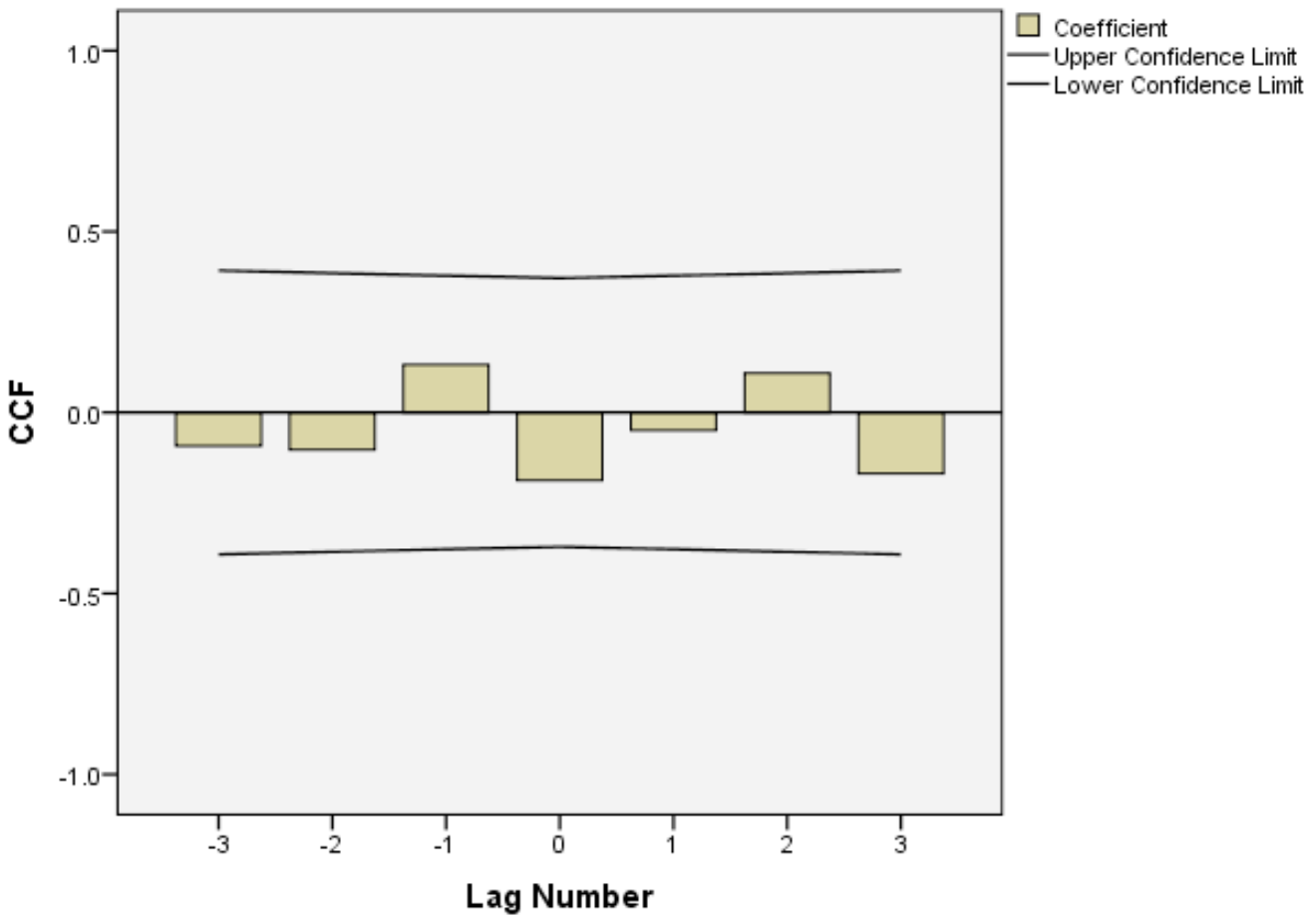




\section{Readers Guide Death Penalty Stories}

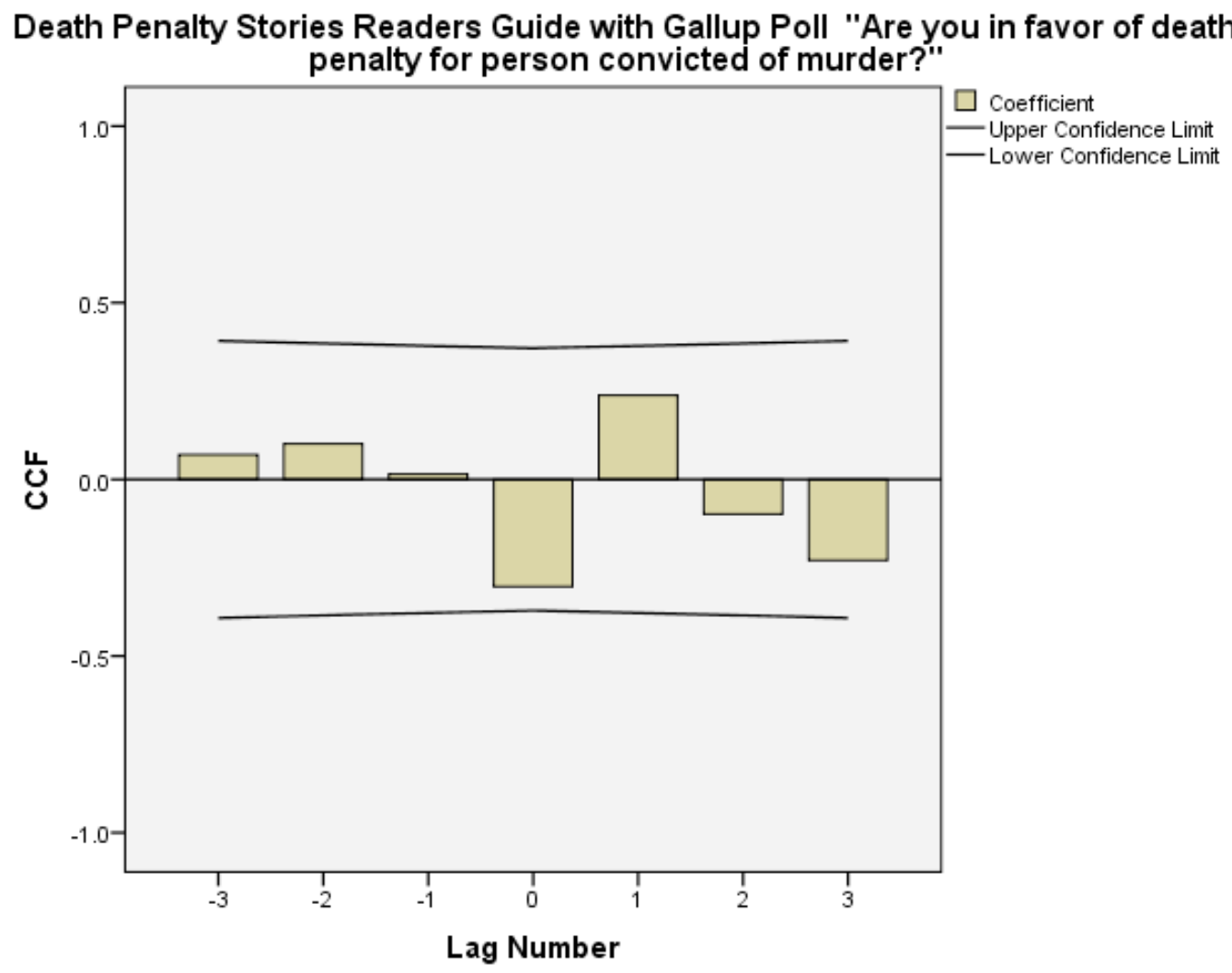

\section{REFERENCES}

Armstrong, Edward. 1993. The rhetoric of vioelnce in rap and country music. Sociological Inquiry 63: 64-83. http://dx.doi.org/10.1111/j.1475-682X.1993.tb00202.x

Baldus, David C., and George Woodworth. 1998. Racial discrimination and the death penalty: An empirical and legal overview. In America's Experiment with Capital Punishment: Reflections on the Past, Present and Future of the Ultimate Penal Sanction, (eds.) James R. Acker, Robert M. Bohm, and Charles S. Lanier. Durham, NC: Carolina Academic Press.

Baumgartner, Frank R., Suzanna L. DeBoef, and Amber E. Boydstun. 2008. The Decline of the Death Penalty and the Discovery of Innocence. Cambridge: Cambridge University Press.

Beckett, Katheine and Ted Sasson. 2000. The Politics of Injustice: Crime and Punishment in America. Thousand Oaks, CA: Pine Forge Press.

Bedau, Hugo Adam. 1987. Death is Different: Studies in the Morality, Law, and Politics of Capital Punishment. Boston: Northeastern University Press.

Binder, Amy. 1993. Constructing racial rhetoric: Media depictions of harm in heavy metal and rap music. American Sociological Review 58: 753-767. http://dx.doi.org/10.2307/2095949

Bohm, Robert M. 1990. Death penalty opinions: Effects of a classroom experience and public commitment." Sociological Inquiry 60: 285-297.

Bohm, Robert M. 1992. Toward an understanding of death penalty opinion change in the United States: The pivotal years, 1966 and 1967." Humanity and Society 16: 524-542.
Bohm, Robert M. 2012. DEATHQUEST: An Introduction to the Theory and Practice of Capital Punishment in the United States. Waltham, MA: Elsevier/Anderson.

Bohm, Robert M., and Brenda L.Vogel. 2004. More than ten years after: The long-term stability of informed death penalty opinions. Journal of Criminal Justice 32: 307-327. http://dx.doi.org/10.1016/j.jcrimjus.2004.04.003

Bohm, Robert M., Louise J. Clark, and Adrian F. Aveni. 1990. The influence of knowledge on death penalty opinions: An experimental test. Justice Quarterly 7: 175-188. http://dx.doi.org/10.1080/07418829000090521

Bohm, Robert M., Louise J. Clark, and Adrian F. Aveni. 1991 Knowledge and death penalty opinion: A test of the Marshall hypotheses. Journal of Research in Crime and Delinquency 28: 360-387. http://dx.doi.org/10.1177/0022427891028003006

Bohm, Robert M., Ronald E. Vogel, and Albert A. Maisto. 1993 Knowledge and death penalty opinion: A panel study. Journal of Criminal Justice 21: 29-45. http://dx.doi.org/10.1016/0047-2352(93)90004-7

Bright, Stephen B. 1998. The politics of capital punishment: The sacrifice of fairness for executions. In America's Experiment with Capital Punishment: Reflections on the Past, Present and Future of the Ultimate Penal Sanction, (eds.) James R. Acker, Robert M. Bohm, and Charles S. Lanier. Durham, NC: Carolina Academic Press.

Bright, Stephen B. and Patrick J. Keenan. 1995. Judges and the politics of death: Deciding between the Bill of Rights and the next election in capital cases. Boston University Law Review 75: 759-835.

Burnett, Cathleen. 2002. Justice Denied: Clemency Appeals in Death Penalty Cases. Boston: Northeastern University Press. 
Callahan, Lisa, James R. Acker, and Catherine Cerulli. 2000. Accommodating death penalty legislation: Personal and professional views of assistant district attorneys toward capital punishment." American Journal of Criminal Justice 25: 15-29. http://dx.doi.org/10.1007/BF02886808

Claussen, Dane S. 2004. Cognitive dissonance, media illiteracy, and public opinion on news media- American Behavioral Scientist, 48 (2): 212-218. http://dx.doi.org/10.1177/0002764204267265

Chermak, Steven. 1998. The presentation of drugs in the news media: The news sources involved in the construction of social problems. In Constructing Crime: Perspectives on Making News and Social Problems (eds.) Potter, G. and Kappeler, V. Long Grove, IL: Waveland Press.

Cochran, John K. and Mitchell B. Chamlin. 2005. Can information change public opinion?: Another test of the Marshall hypotheses. Journal of Criminal Justice 33: 573-584. http://dx.doi.org/10.1016/j.jcrimjus.2005.08.006

Cochran, John K., Beth Sanders, and Mitchell B. Chamlin. 2006. Profiles in change: An alternative look at the Marshall hypotheses. Journal of Criminal Justice 17: 205-226.

Cohen, S. 2002. Folk Devils and Moral Panics: The Creation of the Mods and Rockers. London: UK: Routledge.

Dickson, Brent E. 2006. Effects of capital punishment on the justice system: Reflections of a state supreme court justice. Judicature 89: 278-281.

Dieter, Richard C. 1996. Killing for Votes: The Dangers of Politicizing the Death Penalty Process. Washington, DC: The Death Penalty Information Center.

Dowler, Kenneth. 2003. Media consumption and public attitudes toward crime and justice: The relationship between fear of crime, punitive attitudes, and perceived police effectiveness Journal of Criminal Justice and Popular Culture 10(2): 109126

Ellsworth, Phoebe C. and Lee Ross. 1983. Public opinion and capital punishment: A close examination of the views of abolitionists and retentionists. Crime and Delinquency 29: 116-169. http://dx.doi.org/10.1177/001112878302900105

Fishman, Mark. 1978. Crime waves as ideology. Social Problems, 25 (5), 531-543. http://dx.doi.org/10.2307/800102

Gelles, Richard J., and Murray A. Straus. 1976. Family experience and public support of the death penalty. In Capital Punishment in the United States, (eds.) Hugo Adam Bedau and C. M. Pierce. New York: AMS.

Green, Melanie, and Timothy Brock. 2000. The role of transportation in the persuasiveness of public narratives. Journal of Personality and Social Psychology 79: 701-721. http://dx.doi.org/10.1037/0022-3514.79.5.701

Haines, Herbert H. 1996. Against Capital Punishment: The AntiDeath Penalty Movement in America, 1972-1994. New York: Oxford University Press.

Holbert, Lance, Dhavan Shah, and Nojin Kwak. 2004. Fear, authority and justice: Crime-related TV viewing and endorsements of capital punishment and gun ownership. Journalism and Mass Communication Quarterly 81: 343-363. http://dx.doi.org/10.1177/107769900408100208

Hunnicutt, Gwen, and Kristy Andrews. 2009. Tragic narratives in popular Cutlure: Depictions of homicide in rap music. Sociological Forum 24: 611-630. http://dx.doi.org/10.1111/j.1573-7861.2009.01122.x

Jenkins, P. 1998. The ice age: The social construction of a drug panic. In Constructing Crime: Perspectives on Making News and Social Problems. (eds.) Potter, G. and Kappeler, V., Long Grove, IL: Waveland Press.

Kappeler, Victor., Mark Blumberg, and Gary Potter. 2000. The Mythology of Crime and Criminal Justice. 3d edition. Prospect Heights, IL: Waveland Press.
Kiousis, Spiro. 2001. Public trust or mistrust? Perceptions of media credibility in the information age. Mass Communication \& Society 4(4): 381-403. http://dx.doi.org/10.1207/S15327825MCS0404 4

Kobil, Daniel T. 2003. The evolving role of clemency in capital cases. In America's Experiment with Capital Punishment: Reflections on the Past, Present and Future of the Ultimate Penal Sanction, 2nd ed. (eds.) James R. Acker, Robert M. Bohm, and Charles S. Lanier. Durham, NC: Carolina Academic Press.

Kohlberg, Lawrence and Daniel Elfenbein. 1975. The development of moral judgments concerning capital punishment. American Journal of Orthopsychiatry 45: 614-640. http://dx.doi.org/10.1111/j.1939-0025.1975.tb01191.x

Kubrin, Charis. 2005. Ganstas, thugs, and hustlas: Identity and the code of the street in rap music. Social Problems 52: 360-378. http://dx.doi.org/10.1525/sp.2005.52.3.360

Lawrence, Richard, and Mueller, David. 2003. School shootings and the man-bites-dog criterion of newsworthiness. Youth Violence and Juvenile Justice 1(4): 330-345. http://dx.doi.org/10.1177/1541204003255842

Lipschultz, Jeremy and Michael Hilt. 1999. Mass media and the death penalty: Social construciton of three Nebraska exectuions. Journal of Broadcasting and Electronic Media 43: 236-252. http://dx.doi.org/10.1080/08838159909364487

Lord, Charles G., Lee Ross, and Mark R. Lepper. 1979. Biased assimilation and attitude polarization: The effects of prior theories on subsequently considered evidence. Journal of Personality and Social Psychology 37: 2098-2109. http://dx.doi.org/10.1037/0022-3514.37.11.2098

Niven, David. 2002. Blostering an illusory majority: The effects of the media's portrayla of death penalty support. Social science Quarterly 83: 671-689. http://dx.doi.org/10.1111/1540-6237.00108

Petty, Richard, and J. T. Cacioppo. 1981. Attitudes and Persuasion: Classic and Contemporary Approaches. Dubuque, IA: Wm. C. Brown.

Petty, Richard, and J. T. Cacioppo. 1986. Communication and Persuasion: Central and Peripheral Routes to Attitude Change. New York: Springer-Verlag.

Petty, Richard and D. T. Wegener. 1999. The elaboration likelihood model: Current status and controversies. In Dual Process Theories in Social Psychology. (eds). S. Chaiken and Y. Trope. New York; Guilford Press.

Petty, Richard, Joseph Priester, and Pablo Brinol. 2002. Mass media attitude change: Implications of the elaboration likelihood model of persuasion. In Media Effects: Advances in Theory and Research (eds.) Jennings Bryant and Dolf Zillmann, Mahwah, NJ: Lawrence Erlbaum.

Roomer, D., Jamieson, K., and Aday, S. (2003). Television news and the cultivation of fear of crime. Journal of Communication 53(I): 88-104.

http://dx.doi.org/10.1111/j.1460-2466.2003.tb03007.x

Sarat, Austin and Neil Vidmar. 1976. Public opinion, the death penalty, and the eighth amendment: Testing the Marshall hypothesis. Wisconsin Law Review 17: 171-206.

Shrum L.J. 2002. Media consumption and perceptions of social reality: Effects and underlying processes. In Media Effects: Advances in Theory and Research (eds.) Jennings Bryant and Dolf Zillmann, Mahwah, NJ: Lawrence Erlbaum.

Slater, Michael and Donna Rouner. 2002. Entertainment-education and elaboration likelihood: Understanding the processing of narrative persuasion. Communication Theory 12: 173-191.

Slater, Michael, Donna Rouner, and Marilee Long. 2006. Television dramas and support for controversial public policies: Effects and mechanisms. Journal of Communication 56: 235-252. http://dx.doi.org/10.1111/j.1460-2466.2006.00017.x 
Surette, Raymond. 2007. Media, Crime and Criminal Justice. Belmont, CA: Thomson Wadsworth.

White, Welsh S. 1987. The Death Penalty in the Eighties: An Examination of the Modern System of Capital Punishment. Ann Arbor: University of Michigan Press.

Wright, Harold O., Jr., Robert M. Bohm, and Katherine M. Jamieson. 1995. A comparison of uninformed and informed death penalty opinions: A replication and expansion. American Journal of Criminal Justice 20: 57-87.

http://dx.doi.org/10.1007/BF02886118

Zimring, Franklin E. 2003. The Contradictions of American Capital Punishment. New York: Oxford University Press.

Received on 04-02-2013

Accepted on 25-03-2013

Published on 04-04-2013

DOI: http://dx.doi.org/10.6000/1929-4409.2013.02.5

(C) 2013 Robert M. Bohm; Licensee Lifescience Global.

This is an open access article licensed under the terms of the Creative Commons Attribution Non-Commercial License (http://creativecommons.org/licenses/by-nc/3.0/) which permits unrestricted, non-commercial use, distribution and reproduction in any medium, provided the work is properly cited. 